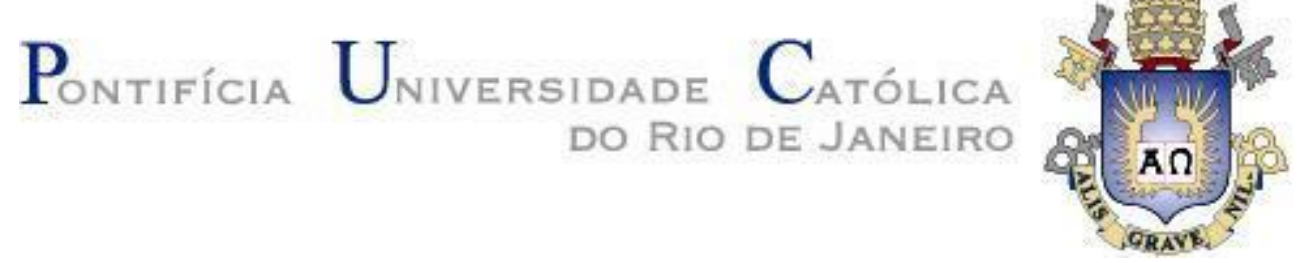

Priscila Correa Franco Amaral

\title{
A CRISE DO COVID-19 NO TURISMO - O CASO DA CAFÉ E VIAGENS
}

Dissertação de Mestrado

Dissertação apresentada como requisito parcial para obtenção do grau de Mestre pelo Programa de Pósgraduação em Administração de Empresas do Departamento de Administração da PUC-Rio.

Orientador: Angela Maria Cavalcanti da Rocha

Rio de Janeiro

Abril de 2021. 
Priscila Correa Franco Amaral

\title{
A crise do COVID-19 no turismo - O caso da Café e Viagens
}

\author{
Dissertação de Mestrado
}

Dissertação apresentada como requisito parcial para obtenção do grau de Mestre pelo Programa de PósGraduação em Administração de Empresas da PUC-Rio. Aprovada pela Comissão Examinadora abaixo.

Prof(a). Angela Maria Cavalcanti da Rocha

Orientadora

Departamento de Administração - PUC-Rio

Jorge Brantes Ferreira

Departamento de Administração - PUC-Rio

Flavia Luiza Oliveira da Cunha Galindo

Departamento de Administração - UFRRJ

Rio de Janeiro, 30 de abril de 2021 
Todos os direitos reservados. É proibida a reprodução total ou parcial do trabalho sem autorização da universidade, do autor e do orientador.

\section{Priscila Corrêa Franco Amaral}

Graduou-se em Administração na UFRRJ (Universidade Federal Rural do Rio de Janeiro) em 2019.

Ficha Catalográfica

Amaral, Priscila Correa Franco

A crise do COVID-19 no turismo : o caso da café e viagens / Priscila Correa Franco Amaral ; orientador: Angela Maria Cavalcanti da Rocha. $-2021$.

82 f. : il. color. ; $30 \mathrm{~cm}$

Dissertação (mestrado)-Pontifícia Universidade Católica do Rio de Janeiro, Departamento de Administração, 2021.

Inclui bibliografia

1. Administração - Teses. 2. Turismo. 3. Covid-19. 4. Crises e desastres. 5. Marketing de relacionamento. I. Rocha, Angela Maria Cavalcanti da. II. Pontifícia Universidade Católica do Rio de Janeiro. Departamento de Administração. III. Título. 


\section{Agradecimentos}

À minha família, por ter me apoiado nesses anos de Mestrado.

Em especial minha esposa Gabriela Andrade e meus pais Luciene Correa e Marco Amaral, que foram fundamentais para a realização de mais este sonho.

Á Angela da Rocha, minha orientadora, pela pessoa e profissional que é. Obrigada por cada comentário, elogios, críticas e incentivos, mesmo durante a pandemia, e principalmente por ter acreditado e depositado sua confiança em mim. Bem como a todos os professores do IAG que tive a oportunidade de conhecer e aprender com as aulas, debates e conversas.

À Flávia Galindo, minha orientadora de iniciação cientifica pela dedicação, competência, apoio e todo conhecimento compartilhado.

Um agradecimento enorme à Gisele Notari,, secretária do departamento, sempre disponível para me ajudar.

Aos meus colegas de turma e de vida não só pelas trocas de material e grupos de estudo, mas também pelo apoio nos momentos de angústia e ansiedade.

À Coordenação De Aperfeiçoamento De Pessoal De Nível Superior (CAPES) pela bolsa e auxílio financeiro para a conclusão desta dissertação.

O presente trabalho foi realizado com apoio da Coordenação de Aperfeiçoamento de Pessoal de Nível Superior - Brasil (CAPES) - Código de Financiamento 001 


\section{Resumo}

Amaral, Priscila C F; da Rocha, Angela M C. A crise do COVID-19 no turismo - O caso da Café e Viagens. Rio de Janeiro, 2021. 82p. Dissertação de Mestrado - Departamento de Administração, Pontifícia Universidade Católica do Rio de Janeiro.

A indústria de turismo foi fortemente afetada pela pandemia do Covid-19, que se alastrou rapidamente por todo o mundo, causando a interrupção mais severa da economia global no século XXI. Sem vacinas e com capacidade médica limitada para tratar a doença, as intervenções não farmacêuticas foram a principal estratégia adotada pelos países para conter a pandemia, resultando em restrições globais de viagens e reclusão domiciliar. Diante deste cenário, pesquisadores de turismo pediram uma resposta proativa em termos de planejamento de gestão em tempos de crise, visto que pandemias têm um impacto destrutivo devastador na indústria de viagens e turismo, principalmente para as pequenas empresas. Esta dissertação descreve os impactos sofridos por uma pequena empresa familiar brasileira de turismo durante a pandemia do Covid-19, as percepções dos empreendedores durante a crise, bem como as estratégias seguidas pela empresa e seu relacionamento com clientes, adotando o método do estudo de caso. A resposta à crise utilizada pela empresa é avaliada e comparada com a literatura. Com base nas descobertas, são extraídas as conclusões do estudo e feitas recomendações para futuras pesquisas.

\section{Palavras- chave}

Turismo; Covid-19; Crises e Desastres; Marketing de relacionamento. 


\section{Abstract}

Amaral, Priscila C F; da Rocha, Angela M C (Advisor). The crisis of COVID-19 in tourism - The case of Café e Viagens. Rio de Janeiro, 2021. 82p. MSc. Dissertation - Departamento de Administração, Pontifícia Universidade Católica do Rio de Janeiro.

The tourism industry was strongly affected by the COVID-19 pandemic, which spread rapidly around the world, causing the most severe disruption of the global economy in the 21 st century. Without vaccines and limited medical capacity to treat the disease, non-pharmaceutical interventions were the main strategy adopted by countries to contain the pandemic, resulting in global travel restrictions and home confinement. Faced with this scenario, tourism researchers asked for a proactive response in terms of management planning in times of crisis, as pandemics have a devastating destructive impact on the travel and tourism industry, especially for small businesses. This dissertation describes the impacts suffered by a small family-owned Brazilian tourism company during the Covid-19 pandemic, the perceptions of the entrepreneurs during the crisis, as well as the strategies followed by the firm and the relationship with customers, adopting the case study method. The response of the firm to the crisis is evaluated and compared with the literature. Based on the findings, the conclusions are presented, as well as suggestions for future research.

\section{Keywords}

Tourism; Covid-19; Crises and disasters; Relationship Marketing; 


\section{Sumário}

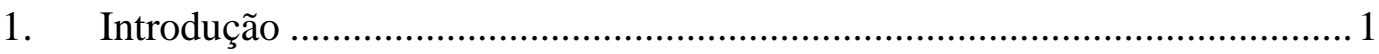

1.1. O problema

1.2. A pandemia do COVID-19 6

1.3. O setor de turismo no Brasil 9

$\begin{array}{ll}\text { 1.4. Relevância do estudo } & 10\end{array}$

1.5. Objetivos do estudo 11

1.6. Organização do estudo 12

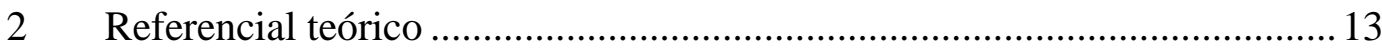

2.1. Crises e desastres no turismo 13

$\begin{array}{ll}\text { 2.2. Gestão de crises e desastres no turismo } & 18\end{array}$

2.2.1. Respostas à crise: papel dos governos .........................................20

2.2.2. Respostas à crise: papel das empresas ....................................... 21

2.3. Marketing de relacionamento 23

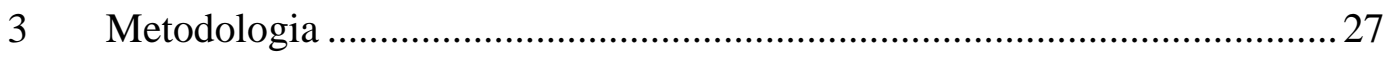

$\begin{array}{ll}\text { 3.1. Perguntas da Pesquisa } & 27\end{array}$

$\begin{array}{ll}\text { 3.2. Método da Pesquisa } & 28\end{array}$

3.3. Método de Coleta de Dados 29

3.4. Análise de Dados 30

3.5. Limitações do Estudo 31

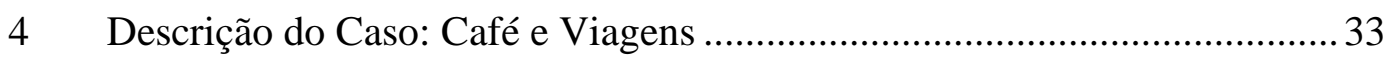

4.1. Histórico da Empresa 33

$\begin{array}{ll}\text { 4.2. Situação antes da Pandemia } & 37\end{array}$

4.3. Impactos Iniciais da Pandemia nos Negócios da Empresa 39 
4.3.1. Mudanças Realizadas no Decorrer da Pandemia............................ 43

4.4. Situação da Empresa na Conclusão do Estudo 48

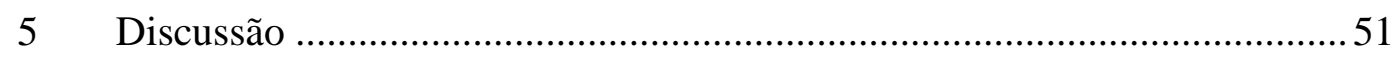

5.1. Evolução de um Pequeno Empreendimento e a Pandemia do Covid-19 51

5.2. Estágios no Decorrer da Pandemia 53

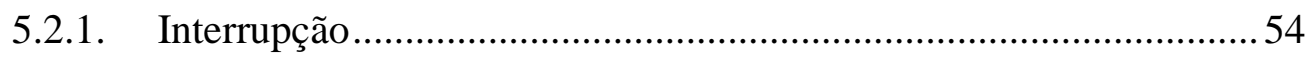

5.2.2. Perda e Resiliência..................................................................... 54

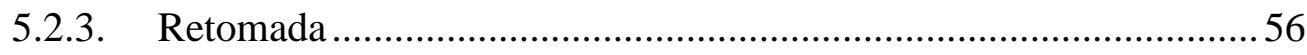

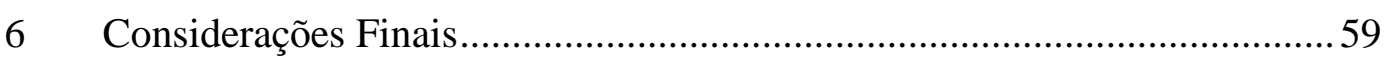

$\begin{array}{lr}\text { 6.1. Conclusões } & 59\end{array}$

6.2. Sugestões e recomendações para novas pesquisas 61

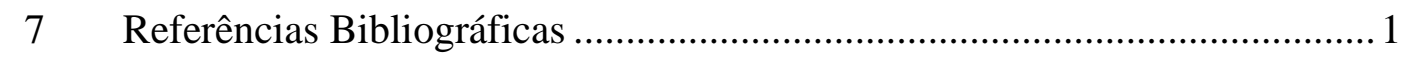




\section{Lista de figuras}

Figura 1- Impacto do Covid-19 no Turismo Internacional .................................... 2

Figura 2 - Participação do setor de viagens no PIB em 2019................................. 3

Figura 3 - Percentual de cancelamentos de reservas no Brasil .............................. 4

Figura 4-Expectativa de recuperação de demanda turística em 2020 e 2021 ..........5

Figura 5 - Número de casos por coronavírus (COVID-19)................................. 7

Figura 6 - : Número de óbitos por coronavírus (COVID-19) …............................. 7

Figura 7 - Mapa global de casos confirmados em outubro de 2020....................... 8

\section{Lista de tabelas}

Tabela 1- Países com ápices de casos e mortes por COVID 19........................... 8

Tabela 2 - Dados do Turismo no Brasil em 2018 e 2019 ...................................... 10

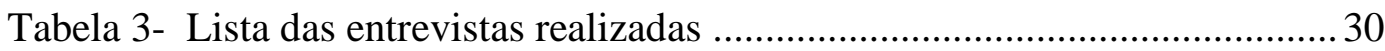

Tabela 4- Agenda divulgada pela Café e Viagens............................................... 49 


\section{Lista de quadros}

Quadro 1- Evolução do Empreendimento ..........................................................51

Quadro 2- Estágios vividos pelos empreendedores ..........................................53

\section{Lista de anexos}

Anexo 1- Roteiro de entrevista semi-estruturado para os sócios da empresa ........ 11 


\section{Introdução}

O propósito desta pesquisa foi contribuir para o entendimento de como pequenos empreendedores do setor de turismo têm entendido, reagido e se posicionado diante dos desafios enfrentados em um período de pandemia. Investigaram-se especificamente os impactos sofridos por uma pequena empresa familiar brasileira de turismo durante a pandemia do Covid-19, as percepções dos empreendedores no decorrer da pandemia, bem como as estratégias empregadas para enfrentar a crise, adotando o método do estudo de caso.

\subsection{O problema}

O turismo como atividade econômica apresenta especificidades quanto à oferta de produtos e serviços disponibilizados para satisfazer as necessidades dos turistas, incluindo transporte, acomodação, agências de viagens, atividades de lazer, entre outros. Dada a multiplicidade de atividades econômicas envolvidas, o setor se encontra bastante exposto a mudanças no ambiente externo. Trata-se, portanto, de uma indústria altamente vulnerável a crises e desastres naturais (Marques et al., 2020), tendo, na última década, vivenciado diversos desses eventos. Como exemplos podem-se citar o terremoto de 2011 no Japão, seguido por uma tsunami, e a epidemia de SARS (Síndrome Respiratória Aguda Grave) em 2002-2003, que afetou 26 países, principalmente os do Sudeste Asiático e a China (WHO, 2020).

Contrariamente aos eventos anteriormente citados, cujos efeitos sobre o turismo se restringiram aos países diretamente afetados, a pandemia do Covid-19 adquiriu proporções globais, atingindo todos os continentes e países. Em decorrência, os impactos da pandemia do Covid-19 sobre viagens aéreas, cruzeiros e acomodações foram devastadores (Gössling et al., 2021; Kaushal e Srivastava, 2021). De acordo 
com o site Statista (2020b), a receita global da indústria de viagens e turismo foi estimada em US\$ 447,4 bilhões em 2020 - uma redução de 34,7\% em relação ao ano anterior. Além disso, o valor é significativamente menor do que a previsão original para 2020, de cerca de 710 bilhões de dólares. Como resultado da pandemia, o mercado global de viagens e turismo previa, em 2020, uma perda de 75,2 milhões de empregos e uma forte redução da parcela do Produto Interno Bruto (PIB) gerado por viagens e turismo em todo o mundo. A Figura 1 compara a redução no turismo internacional de janeiro a outubro de 2020 com o mesmo período do ano anterior.

\section{COVID-19's Crushing Impact On International Tourism}

Change in international tourist arrivals from January

through October 2020 vs. 2019

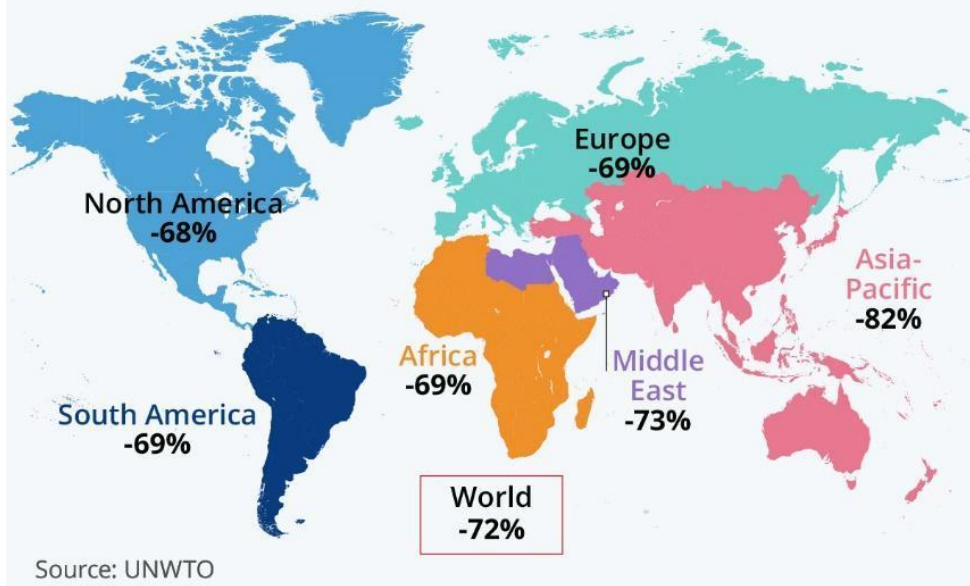

(c) 9

statista 5

Figura 1- Impacto do Covid-19 no Turismo Internacional

Fonte: Statista (2021)

O turismo é uma das principais indústrias em muitos países, tais como Espanha e Itália, na Europa, e México e países do Caribe, nas Américas (Figura 2). Com a proibição de viagens internacionais afetando mais de $90 \%$ da população mundial e restrições generalizadas a reuniões públicas e à mobilidade social, o turismo cessou em grande parte do mundo em março de 2020, com a eclosão global da pandemia (Gössling et al., 2021). Estimava-se que o Brasil, país mais populoso da América Latina, poderia perder até 1,2 milhão de empregos na indústria de turismo e viagens (Statista, 2020a). Apesar de grandes empresas participarem da indústria, como 
redes hoteleiras, companhias aéreas e empresas de cruzeiros marítimos, o setor abriga também ampla diversidade de pequenas empresas- como agências de viagem independentes, pousadas, lojas de souvenirs, cafés, lanchonetes e pequenos restaurantes, dentre muitos outros serviços - que sofreram consequências significativas (Castro e Zermeño, 2020) e que podem não dispor dos recursos e capacidades necessários para se recuperarem rapidamente (Mair et al., 2016; Pforr e Hosie, 2008).

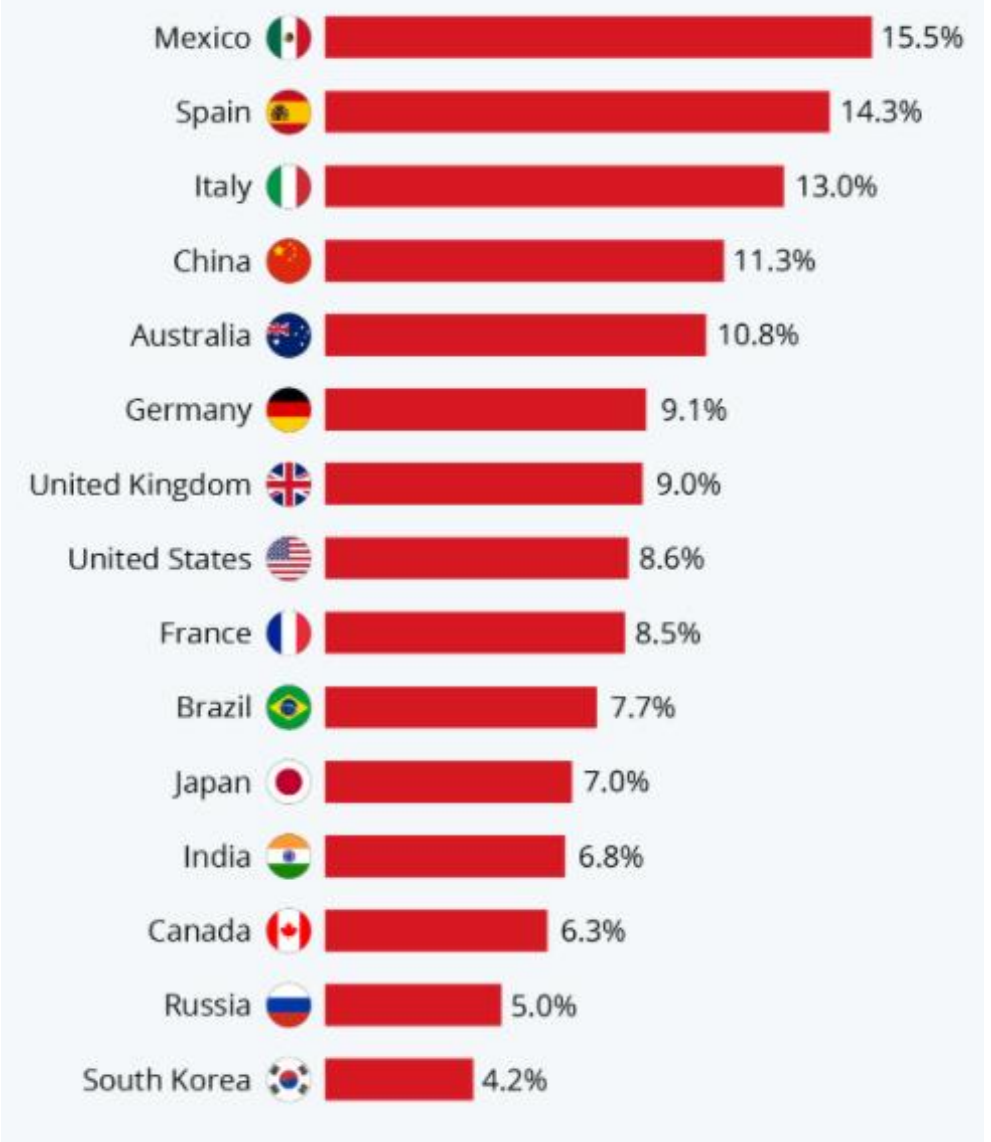

Figura 2 - Participação do setor de viagens no PIB em 2019.

Fonte: Elaborado por Statista (2020d) com base em dados do World Travel \& Tourism Council (WTTC).

Além dos impactos decorrentes de sua própria ocorrência, os eventos críticos são amplamente divulgados pela mídia, em âmbito global, o que pode não só conscientizar, mas também amplificar a percepção das crises. Entretanto, no período pós-crise, a comunicação é frequentemente negligenciada, o que pode 
aumentar a percepção de risco pessoal por parte dos turistas e tornar mais difícil e lenta a recuperação da confiança (Ghaderi et al., 2012; Pforr e Hosie, 2008).

Diante deste cenário, mudanças de estilo de vida já foram identificadas na China, Alemanha, Reino Unido e Estados Unidos devido à pandemia. Em uma pesquisa com 2.840 respondentes desses países, em 2020, pelo menos $50 \%$ afirmaram ter a intenção de viajar menos. Havia dúvidas, ainda, sobre quando os clientes se sentiriam confiantes o suficiente para se envolver nessas atividades novamente. No Brasil, em abril de 2020, cerca de 50\% das reservas relacionadas a viagens e turismo feitas através do TravelgateX (Figura 3) foram canceladas, somando-se à redução de quase $25 \%$ ainda no mês de março, seguindo-se uma redução gradual no número de cancelamentos nos meses subsequentes (Statista, 2020c).

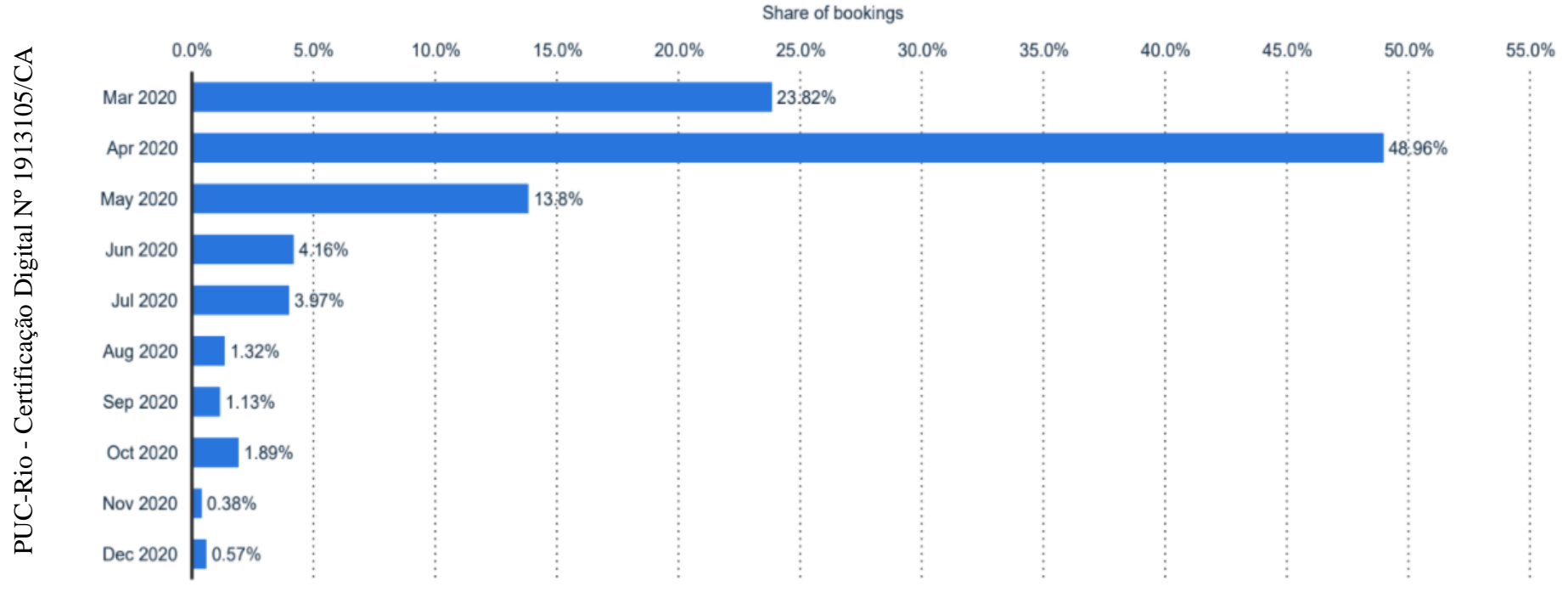

Figura 3 - Percentual de cancelamentos de reservas no Brasil em março de 2020, por mês.

Fonte: Statista, 2020c.

Quanto às expectativas de recuperação do setor, de acordo com a pesquisa do Painel de Especialistas da OMT (UNWTO, 2020), com base nas crises anteriores, esperava-se que a demanda doméstica retornasse mais rapidamente do que a demanda internacional. Além disso, os especialistas viam um potencial de recuperação mais rápido para viagens familiares e de lazer do que para viagens de 
negócios. Embora altamente incertas, as primeiras projeções da OMT para 2020 sugeriram que, em algumas regiões do mundo, a recuperação poderia ocorrer no último trimestre de 2020 (Figura 4). No entanto, para as Américas o cenário era menos otimista.

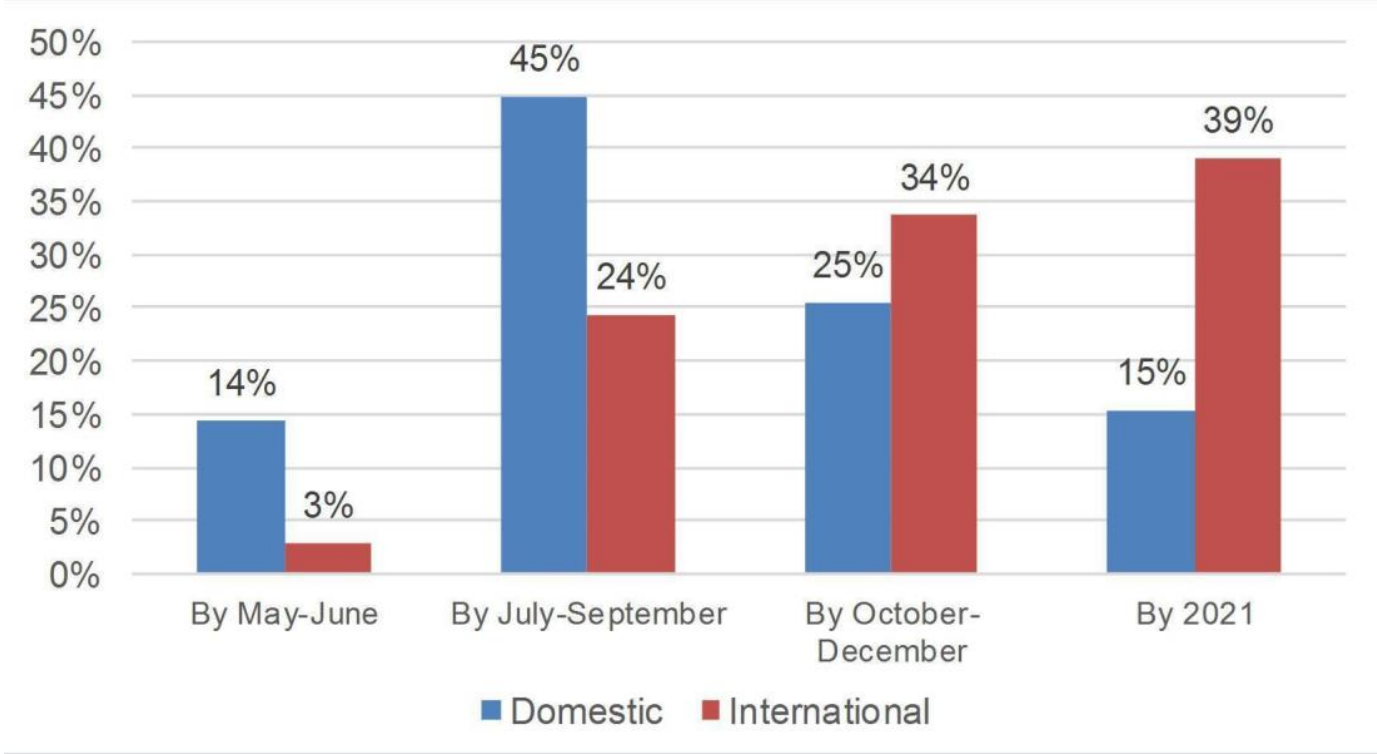

Figura 4-Expectativa de recuperação de demanda turística em 2020 e 2021.

Fonte: UNWTO Reports (2020)

Estas expectativas acabaram por se revelar otimistas, uma vez que, no começo de 2021, com diversos países enfrentando a terceira onda da pandemia, inclusive o Brasil, muitas fronteiras permaneciam fechadas e muitos deles encaravam a suspensão de diversas atividades econômicas.

Considerando este cenário, o presente estudo investigou as reações dos empreendedores de uma empresa brasileira de turismo, familiar e de pequeno porte, durante parte da pandemia do Covid-19, entre março de 2020 e outubro de 2020. Com o propósito de buscar um entendimento mais profundo de como empreendedores em pequenas empresas de turismo percebem, reagem e buscam soluções diante dos desafios ocasionados por uma crise externa de grandes proporções, optou-se por utilizar o método do estudo de caso. Esta abordagem se apresenta particularmente adequada à exploração de novas situações de pesquisa, uma vez que permite descrever a evolução de uma situação, por meio de uma abordagem longitudinal, os detalhes que a caracterizam e as percepções e atitudes 
dos tomadores de decisão, assim como compreender melhor as decisões tomadas em resposta à crise. Assim sendo, o método proporciona visão mais profunda e abrangente, permitindo a obtenção de entendimentos e evidências preliminares que apoiem estudos quantitativos futuros sobre as reações das empresas a grandes eventos disruptivos.

\subsection{A pandemia do COVID-19}

Segundo a Organização Mundial de Saúde (OMS), em 31 de dezembro de 2019 casos de pneumonia de causa desconhecida foram notificados na cidade de Wuhan, China, e em 7 de janeiro de 2020 as autoridades chinesas identificaram como causa um novo coronavírus. Os coronavírus fazem parte de uma grande família de vírus que causam doenças respiratórias desde casos mais brandos até casos mais graves. Um novo coronavírus é uma nova cepa não identificada anteriormente em humanos.

Em decorrência do alerta emitido pela China, países ao redor do mundo aumentaram sua vigilância para diagnosticar rapidamente novos casos potenciais do vírus (WHO/Europe, 2020). No Brasil, o primeiro caso foi confirmado na cidade do Rio de Janeiro em 25 de fevereiro de 2020, sendo declarado caso de emergência pública em 16 de março de 2020 (Dantas et al., 2020). De 26 de fevereiro a 17 de outubro de 2020, os casos brasileiros confirmados e notificados cresceram rapidamente, sendo confirmados 5.224.362 casos (Figura 5) e 153.675 óbitos (Figura 6). 


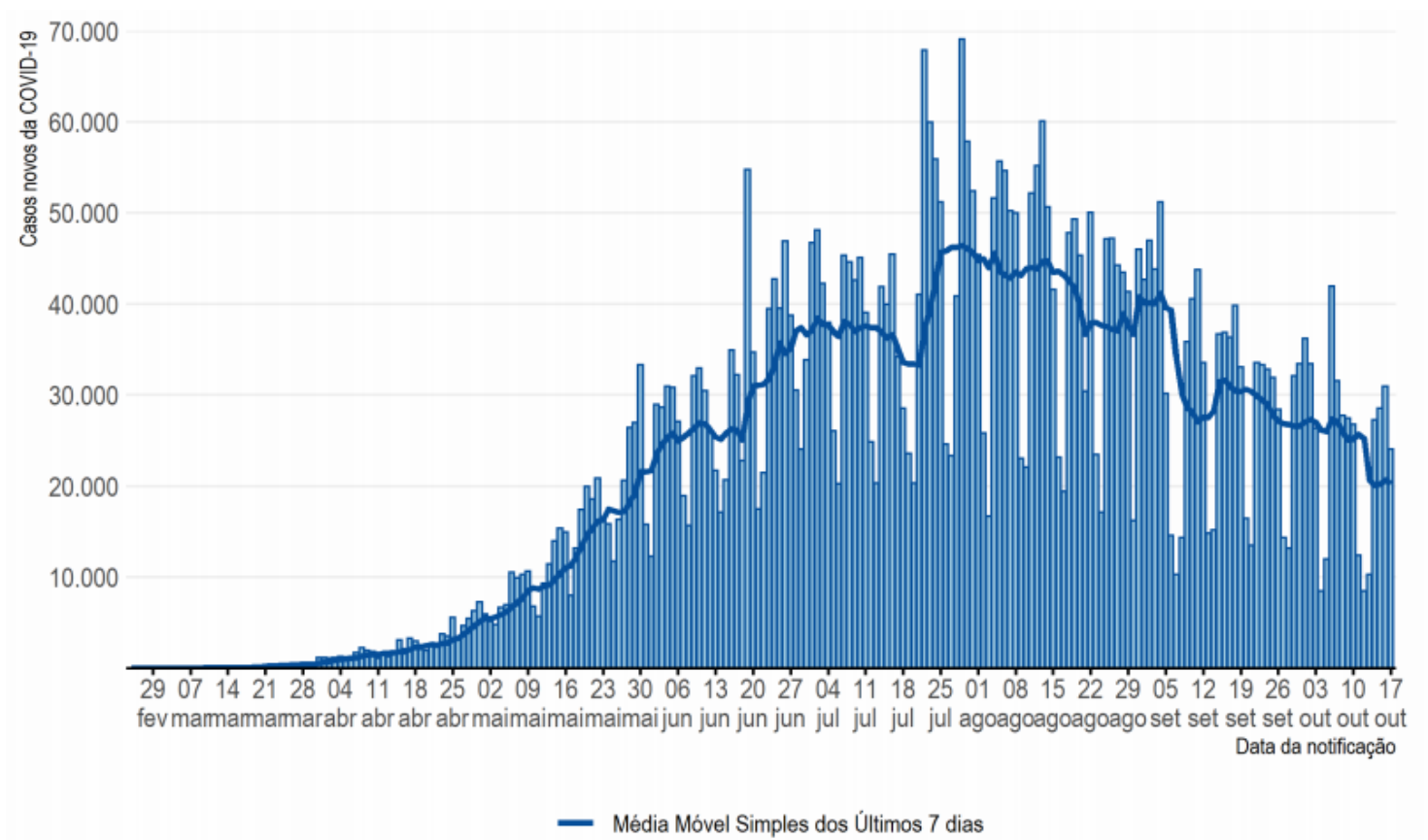

Figura 5 - Número de casos por coronavírus (COVID-19) confirmados no Brasil por data de notificação de 26 de fevereiro a 17 de outubro de 2020.

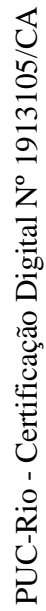

Fonte: Brasil (2020c)

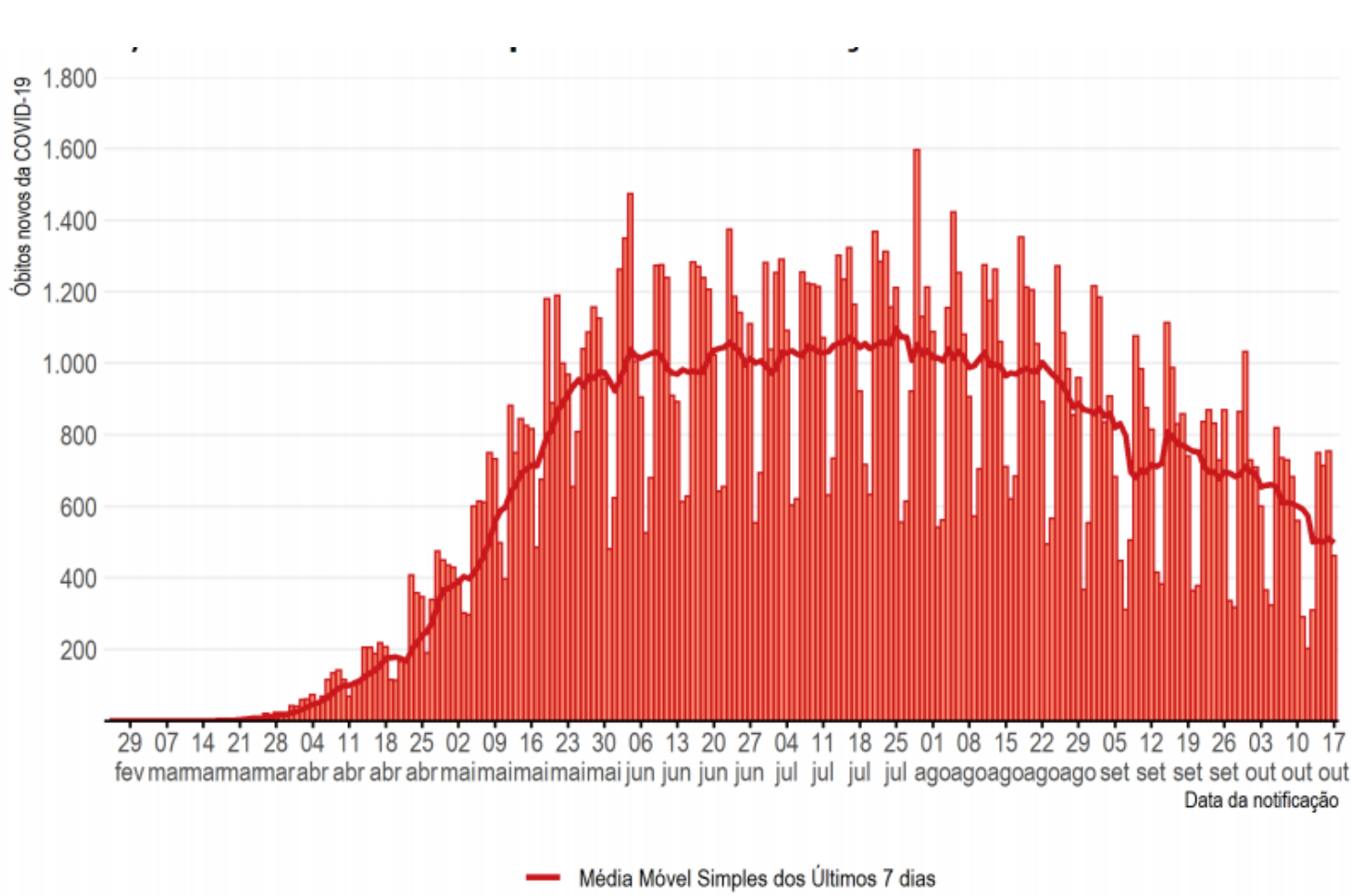

Figura 6 - : Número de óbitos por coronavírus (COVID-19) confirmados no Brasil por data de notificação de 26 de fevereiro a 17 de outubro de 2020.

Fonte: Brasil (2020c) 
Diferentemente de outras doenças infecciosas, o Covid-19 afeta tanto países considerados desenvolvidos como em desenvolvimento (Souza et al., 2020), tendo casos confirmados em todos os continentes (Figura 7), chegando a 40.489.201 casos confirmados em outubro de 2020 (Hopkins, 2020). Os países com maiores concentrações de casos eram Estados Unidos, Índia, Brasil, Rússia, Argentina e Espanha (Tabela 1). Em relação ao panorama global do número de mortes foram registrados 1.119.620 óbitos até outubro de 2020, sendo Estados Unidos, Brasil, Índia, México e Reino Unido os países que tiveram maiores registros (Tabela 1).

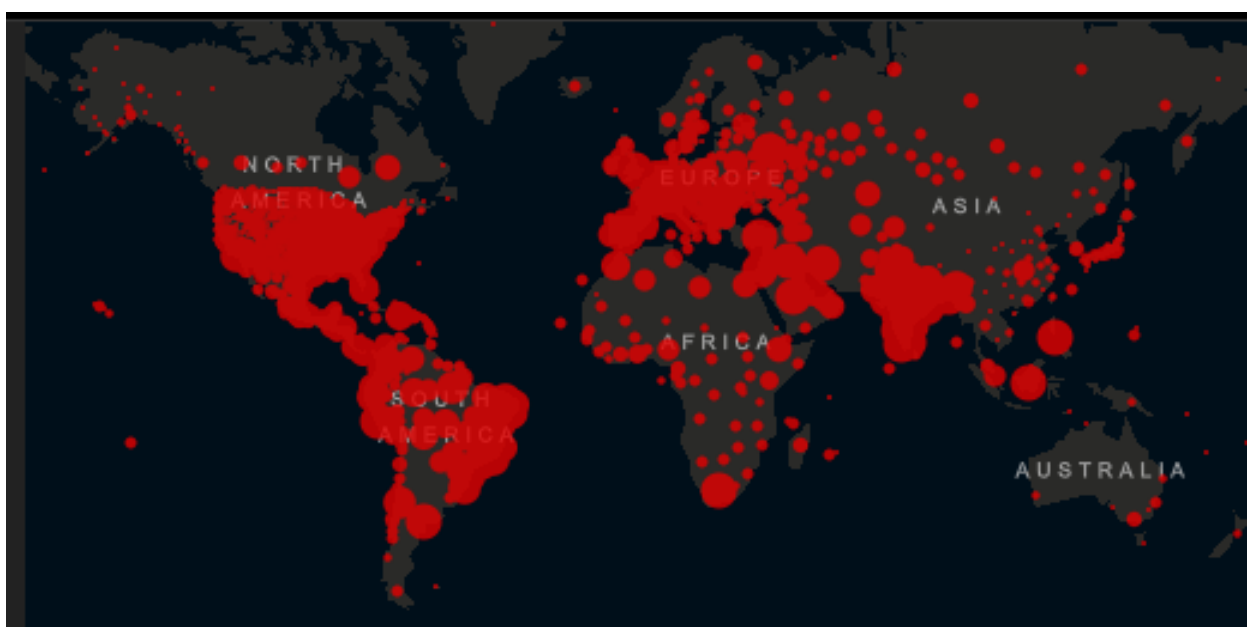

Figura 7 - Mapa global de casos confirmados em outubro de 2020.

Fonte: John Hopkins University of Medicine. Coronavirus Research Center (2020).

Tabela 1- Países com ápices de casos e mortes por COVID 19.

\begin{tabular}{|l|l|l|l|}
\hline País & $\begin{array}{l}\text { Casos } \\
\text { confirmados }\end{array}$ & País por \\
\hline $\begin{array}{l}\text { Estados } \\
\text { Unidos }\end{array}$ & 8.217 .952 & Estados Unidos & 220.185 \\
\hline COVID 19
\end{tabular}




\begin{tabular}{|l|l|l|l|}
\hline Espanha & 974.449 & Itália & 36.616 \\
\hline
\end{tabular}

Fonte: John Hopkins University of Medicine. Coronavírus Research Center (2020).

O Covid-19 se espalhou pelo mundo a uma taxa alarmante, tornando-se uma pandemia, causando a interrupção mais severa da economia global desde a Segunda Guerra Mundial (Gössling et al., 2021; Qiu et al., 2020). Inicialmente sem vacinas e com limitada capacidade médica e hospitalar para tratar a doença, as intervenções não farmacêuticas tornaram-se a principal estratégia para conter a pandemia, resultando em restrições globais de viagens e notificações de reclusão domiciliar sem precedentes, sendo a pandemia do Covid-19 considerada um dos eventos mais impactantes do século 21 (Zenker e Kock, 2020). Segundo Farzanegan et al. (2020), os países expostos a altos fluxos de turismo internacional foram aqueles onde ocorreu inicialmente maior número de casos e óbitos, como Espanha e Itália. Neste contexto, os estudiosos do turismo direcionaram sua atenção às comunidades em destinos turísticos, avaliando sua segurança e bem-estar e os custos incorridos em decorrência da cessação da atividade turística (Qiu et al., 2020).

\section{3. $\mathrm{O}$ setor de turismo no Brasil}

O Brasil possui um conjunto de recursos naturais, culturais e sociais que o insere no turismo mundial, mas, por estar em desenvolvimento, requer políticas públicas e iniciativas privadas que atendam às demandas do turismo e demais setores econômicos (Marques et al., 2020).

Os megaeventos Copa do Mundo, em 2014, e Olimpíadas, em 2016. despontaram como sinalizadores de visibilidade mundial para o turismo no Brasil, em virtude de sua extensão territorial preenchida por peculiaridades capazes de encantar os visitantes. A realização desses megaeventos demandou investimentos em infraestrutura, para dar suporte ao aumento do fluxo turístico para as cidades anfitriãs. Em decorrência desta demanda, o Brasil se tornou um dos países com maior potencial de desenvolvimento de transporte aéreo, quando comparado a 
outros países emergentes (Marques et al., 2020). Assim, tais eventos levaram o Brasil a uma expectativa de maior inserção no mercado turístico internacional.

O setor de turismo brasileiro vinha apresentando um histórico de demanda crescente nos anos que precederam a pandemia, tanto nacional quanto internacional (Mangialardo et al., 2019). Em 2019, o turismo brasileiro recebeu 6,35 milhões de turistas, um número inferior ao do ano anterior, mas mesmo assim registrou um aumento na receita cambial turística de 2,6\% em relação a 2019 (Brasil, 2020a), conforme a Tabela 2. Nesse período, nove das 12 unidades federativas pesquisadas registraram crescimento. Os destaques ficaram com os estados do Ceará $(5,4 \%)$, São Paulo (5,1\%), Minas Gerais (2,5\%) e Rio de Janeiro (2,3\%). Entre os destinos mais populares estavam, antes da pandemia, as cidades de São Paulo, Rio de Janeiro, Curitiba, Salvador e Fortaleza (Souza et al., 2020).

Tabela 2 - Dados do Turismo no Brasil em 2018 e 2019

\begin{tabular}{|c|c|c|}
\hline Turismo no Brasil & 2018 & 2019 \\
\hline Chegadas de Turistas ao Brasil (milhões) & 6,62 & 6,35 \\
\hline Receita cambial turística (bilhões de US\$) & 5,92 & 5,99 \\
\hline
\end{tabular}

Fonte: Brasil (2020b)

Apesar do cenário favorável ao setor de turismo nos últimos anos, os impactos da pandemia foram bastante severos, com redução drástica de atividades, embora os dados para 2020 ainda não se encontrassem disponíveis por ocasião da conclusão deste trabalho.

\subsection{Relevância do estudo}

Este estudo deriva sua relevância tanto de sua inserção teórica quanto prática. Em uma revisão de literatura realizada por Mair et al. (2016), observou-se que os estudos relacionados à gestão de crises e desastres no turismo enfatizavam os impactos no mercado e a visão do consumidor, mas nenhum estudo examinava 
ações empresariais durante uma pandemia. Segundo Castro e Zermeno (2020), empresas de pequeno e médio porte foram gravemente afetadas pelo fechamento de fronteiras e distanciamento social em decorrência da pandemia do Covid-19, resultando na falência ou fechamento de muitas destas empresas, afetando diretamente as famílias dos empreendedores. Os autores destacam a importância de estudos sobre como empreendedores de pequenas e médias empresas superam tais adversidades, de forma a compreender melhor como gerenciar crises buscando a diminuição dos impactos sofridos. Portanto, as percepções de pequenos empreendedores e as respostas à pandemia no âmbito do negócio constituem um campo aberto à investigação.

Assim sendo, do ponto de vista teórico, há necessidade de expandir o conhecimento no campo do turismo no que diz respeito às respostas a crises e desastres naturais, tanto no que se refere ao processo decisório de pequenas empresas empreendedoras, quanto no que trata da comunicação entre as partes interessadas (Mair et al., 2016; Pforr e Hosie, 2008). Desta forma, o presente estudo pode contribuir para a compreensão do fenômeno e para a geração de insights teóricos sobre o tema.

Do ponto de vista prático, o estudo também traz contribuições aos empreendedores e gerentes de pequenos negócios de turismo, ao analisar a tomada de decisões rápidas e as estratégias utilizadas para enfrentar a crise.

Para o governo, a contribuição do estudo está diretamente relacionada ao interesse na recuperação e expansão futura do turismo no Brasil e, em especial, no Estado do Rio de Janeiro. Ao entender carências e dificuldades de pequenos empreendedores da indústria do turismo, é possível oferecer subsídios à formulação de políticas públicas adequadas para estimular e apoiar estes pequenos negócios.

\subsection{Objetivos do estudo}

O objetivo deste estudo foi identificar e compreender os impactos causados pela pandemia do Covid-19 sobre uma empresa familiar do setor de turismo, investigando a forma como se alteraram as percepções e atitudes dos 
empreendedores ao longo da pandemia, e como essas reações se traduziram em decisões para permitir a continuidade e sobrevivência do negócio.

\subsection{Organização do estudo}

Este trabalho está organizado em seis capítulos, como descrito a seguir:

Neste primeiro capítulo são apresentados a introdução, o problema, os objetivos e a relevância da pesquisa. No segundo capítulo é feita uma revisão da literatura existente sobre crises e desastres no turismo, gestão de crises e uso do marketing de relacionamento. No terceiro capítulo descreve-se a metodologia adotada, com a definição do método de pesquisa escolhido - o estudo de caso, sua aplicação no presente estudo e limitações. O quarto capítulo descreve o caso da empresa estudada - Café e Viagens - incluindo um breve histórico da empresa, o impacto inicial da pandemia , como evoluíram as percepções dos empreendedores e quais as decisões tomadas e ações empreendidas. No quinto capítulo, é feita a discussão dos resultados e no sexto são apresentadas as conclusões e recomendações para estudos futuros. 


\section{Referencial teórico}

Neste capítulo são discutidos aspectos teóricos e estudos relacionados ao tema de investigação. Esta seção está dividida em três partes. A primeira aborda crises e desastres no contexto do turismo e suas implicações para as partes interessadas. $\mathrm{Na}$ segunda, discute-se a gestão de crises e desastres no setor do turismo. Por fim, na última seção, examina-se o marketing de relacionamento como instrumento para a gestão de crises no turismo.

\subsection{Crises e desastres no turismo}

Para Prideaux et al. (2003), os gestores são atormentados pela dificuldade de prever as atividades econômicas futuras, particularmente em momentos de incerteza, como em períodos de crises e desastres. Segundo os autores, crises “... podem ser descritas como resultados falhos, possíveis, mas inesperados, precedidos ou não de ação humana e que impactam gestões preocupadas com os acontecimentos futuros", e desastres como “... mudança imprevisível e catastrófica que normalmente só pode ser respondida após o evento, seja por meio de planos de contingência já implementados ou por meio de uma resposta reativa" (p. 478). Os autores classificam como desastres: desastres naturais de todos os tipos, incluindo inundações, secas e terremotos; mudanças climáticas naturais de longo prazo (distintas dos impactos do aquecimento global induzido pelo homem); e, como pandemias, aquelas causadas por novas cepas de gripe ou por outras doenças.

Castro e Zermeno (2020), em uma revisão sistemática de literatura, identificaram crises relacionadas a: (i) riscos econômicos, como uma crise financeira global, aumento de custos, criação de barreiras institucionais ou impacto no consumo dos clientes; (ii) riscos ambientais, como, por exemplo, mudanças climáticas, perda de biodiversidade, ou desastres naturais; (iii) riscos geopolíticos, especialmente 
conflitos regionais responsáveis por crises econômicas e mudanças institucionais, guerras, revolução política e fracasso de políticas institucionais que prejudicam o empreendedorismo; (iv) riscos sociais, como atos de vandalismo sofridos com consequências negativas para a estabilidade social da comunidade; e (v) crises que combinam vários tipos de riscos, como econômicos, ambientais, geopolíticos e sociais. Os autores salientam que, para que os empreendedores de pequenas e médias empresas possam minimizar o impacto decorrentes de crises, devem conhecer os tipos de riscos a que seus negócios estão sujeitos e como podem vir a ser impactados.

A indústria de turismo é particularmente sensível a eventos críticos (Sigala, 2020). Seja em decorrência de crises ou desastres, os fluxos turísticos internacionais estão sujeitos a interrupções, que podem ocorrer nos próprios destinos, em destinos concorrentes, nos mercados de origem, ou podem estar distantes de qualquer um deles. As consequências podem ser leves e relativamente curtas ou podem ter impactos catastróficos. Grandes interrupções podem ser sentidas tanto em áreas de origem quanto de destino, afetam tanto o setor público quanto o privado e interrompem os planos de viagem pretendidos. Além disso, também devem ser considerados os impactos de interrupções únicas ou múltiplas que ocorrem simultaneamente, ou em uma sequência, que podem criar condições políticas, sociais e econômicas inesperadas, podendo causar o declínio de alguns destinos, o crescimento de novos, ou distúrbios radicais nos fluxos turísticos globais (Prideaux et al., 2003).

Como sempre há uma crise em algum lugar do mundo, o setor parece estar sob ameaça quase permanente de mais uma crise iminente (Pforr e Hosie, 2008). Como as crises no turismo não são um fenômeno novo, os autores destacam duas justificativas para a importância deste debate. A primeira, baseando-se na suposição de que a percepção sobre tais ameaças tenha mudado em decorrência da frequência recente de eventos negativos, visto que o período decorrido entre a ocorrência de catástrofes estaria constantemente encurtando. A segunda, em decorrência da comunicação de massa global, propensa a eventos negativos, propagados rapidamente e de forma sensacionalista, que contribuem para as crises serem 
incorporadas à consciência coletiva. Seja qual for a razão subjacente para que as crises tenham destaque, essa sensibilidade aumentada pode gerar medo em potenciais turistas, aumentando a percepção de risco pessoal. Como a percepção de risco se apresenta como um dos principais fatores que influenciam o comportamento do consumidor de turismo, as organizações devem se preparar para potenciais riscos, tanto para seus estabelecimentos em particular quanto para a indústria turística em geral. Sigala (2020), por sua vez, sugere que uma crise cria oportunidades para mudanças e inovação na indústria de turismo.

Além dos empreendimentos turísticos diretamente afetados por um evento crítico, há aqueles indiretamente afetados, já que, de alguma forma, encontram-se relacionados aos primeiros. Por exemplo, empresas varejistas e diversos tipos de serviços podem ser fortemente afetados pela interrupção de atividades turísticas, o que Qiu et al. (2020, p.1) denominaram de "sistema interconectado de negócios e outros stakeholders que formam um destino turístico". Foo et al. (2020) examinam de que forma a indústria de turismo na Malásia foi atingida pela pandemia do Covid-19, em particular linhas aéreas e hotéis, assim como o impacto sobre os empregados nesses setores. Entre os stakeholders encontram-se também os residentes nas comunidades sediadas no destino turístico, que podem incorrer em custos elevados quando um evento crítico, como uma pandemia, afeta esse destino. Lapointe (2020) sugere que a pandemia do Covid-19 propiciou que a indústria de turismo desse maior atenção às comunidades nos destinos turísticos.

O consumidor de serviços de turismo é também afetado, quer por se encontrar na região ou regiões afetadas, quer por ficar impedido de exercer a atividade turística. O desenvolvimento de padrões e preferências de turismo, principalmente quando se trata de decisões familiares, é um processo complexo que, por estar muito atrelado ao curso da vida individual, não é suficientemente explicado pelas abordagens tradicionais. Quando se trata de consumidores idosos - um dos principais segmentos atingidos pela indústria do turismo - os impactos podem ser muito maiores, uma vez que esses consumidores podem ter maior dificuldade para transferir uma viagem para o futuro, já que sua atividade turística sofre grande 
interferência dos eventos da vida, como nascimento de netos, doenças próprias ou de parentes etc. (Huber et al., 2019).

Os indivíduos de Terceira Idade, tanto no Brasil quanto em outros países, são consumidores relevantes de serviços de turismo, por disporem de tempo e alocarem uma parcela relevante de sua renda a atividades de lazer (Amaro, 2007; Araujo, 2015), dado que frequentemente não puderam fazê-lo em fases anteriores da vida, por compromissos familiares e de trabalho. De fato, o consumo de lazer nesta etapa da vida se apresenta como um dos responsáveis pelo processo de adaptação e mudança social, que permite ao idoso integrar-se socialmente e desenvolver novas atividades. Como verificaram diversos autores, o lazer pode permitir ao idoso representar diferentes papéis do que os que tradicionalmente lhe eram atribuídos (Araujo, 2015), evitando o sentimento de inutilidade a que podem se entregar (Horton e Hunt, 1981). Dessa forma, os idosos apresentam um processo de reconstrução da identidade através do consumo de lazer e das relações sociais estabelecidas desta forma (Araujo, 2015; Barnhart; Peñaloza, 2013; Huber et al., 2019). Por formarem um grupo de consumidores de turismo particularmente impactado por crises, este segmento foi particularmente atingido pela pandemia do Covid-19, principalmente devido ao potencial de risco dessa população, com direcionamento de ações e estratégias de distanciamento social especificamente para esse grupo. As medidas de distanciamento social estão voltadas para a preservação da saúde, mas reduzem a autonomia e a independência do idoso, consideradas alicerces para o envelhecimento saudável. Alguns estudos mostram, no entanto, que a pandemia também fez aflorar comportamentos de ageísmo, julgamentos e ridicularização do idoso (Goldani, 2010; Hammerschmidt et al., 2020).

Com relação aos consumidores em geral, Sigala (2020) sugere que será necessário, em um futuro pós-Covid, examinar de que forma o distanciamento social afetou e afetará as práticas de turismo e lazer. Em que medida tais práticas serão alteradas, ou os consumidores retornarão aos hábitos de turismo e lazer anteriores? Indaga-se ainda a autora se a prática do distanciamento social afetará as percepções de espaço social dos indivíduos, com implicações para os serviços de turismo. Kock et al. 
(2020, p.1), por sua vez, embora reconhecendo a dificuldade de realizar predições quanto ao comportamento futuro do consumidor de turismo, sugerem que podem ocorrer fortes mudanças, cujo impacto no turismo pode ser de "proporções sísmicas". Romagosa (2020, p.691) sugere que "uma das mais prováveis consequências será o foco do consumidor no turismo de proximidade [...] entendido como turismo e viagens próximas de casa".

A possibilidade de uma mudança no comportamento e nas preferências de consumo turístico podem ser justificadas pelas consequências da pandemia, tais como: crise na saúde, crise econômica, restrições de mobilidade social e fechamento de fronteiras. Esses fatores levam a mudanças no consumo, não só pela redução do poder de compra, mas também por gerar maior consciência sócio ambiental, que por sua vez levam a uma percepção de menor risco de exposição ao vírus em viagens de curta distância e duração (Romagosa, 2020). Nesta mesma linha, Seraphin e Dosquet (2020) argumentam que o turismo baseado em uma segunda residência e turismo de montanha devem se inserir entre as alternativas preferidas pelo consumidor em um mundo pós-Covid-19. Por sua vez, Sheth (2020) faz uma reflexão sobre as mudanças nos hábitos dos consumidores provocadas pela pandemia e o impacto que poderão ter em suas ações futuras, sugerindo que hábitos modificados e novos hábitos deverão emergir em resposta às novas experiências no decorrer da pandemia e às ações governamentais, na forma de leis e regulamentação de atividades.

Uma questão que tem sido tratada com frequência na literatura sobre Covid-19 e turismo é a discussão sobre sustentabilidade do turismo (Galvani et al., 2020; Koh, 2020). A não sustentabilidade do modelo de desenvolvimento vigente em negócios de turismo têm inspirado inúmeras pesquisas acadêmicas nos últimos anos e vem adquirindo centralidade no contexto da pandemia da Covid-19. O debate crítico sobre o turismo, seus significados contemporâneos e seus efeitos no contexto de uma sociedade em crise são trazidos por Irving et al. (2020), visando discutir alternativas possíveis para o planejamento turístico no pós-pandemia da Covid-19. O tema da sustentabilidade no turismo vem sendo prioritariamente abordado em pesquisa e políticas públicas principalmente pela via operacional do mercado, 
enquanto as nuances socioambientais e éticas associadas a esse debate estão cada vez mais evidentes em uma projeção de futuro, pressupondo novas epistemologias para apreensão desse fenômeno complexo e contemporâneo. No estudo de Fontoura et al., (2020), que investiga os impactos da pandemia de coronavírus na indústria do turismo, as mudanças na demanda por sustentabilidade no turismo foram discutidas e os resultados indicaram que, embora o setor tenha parado quase inteiramente, há uma oportunidade para o renascimento de um turismo mais sustentável. Soluções como uso de realidade aumentada e turismo virtual também foram propostas (por exemplo, Mohanty et al., 2020). Apesar de serem opções válidas, dificilmente, porém, substituiriam o turismo real no mundo pós-pandemia, mas passariam a ser um complemento a ele.

\subsection{Gestão de crises e desastres no turismo}

Por sua própria natureza esporádica e inesperada, os chamados eventos críticos em particular as pandemias e os desastres naturais - vinham sendo tratados de forma pouco sistemática na literatura de gestão de turismo. Estudos voltados para identificar formas similares de risco no contexto de turismo e viagens já haviam sido publicados desde a década de 1980 (Williams e Baláz, 2013). Contudo, uma abordagem conceitual mais sistemática e robusta sobre como negócios de turismo reagem a crises originárias de eventos críticos não apareceu até a década de 2000, quando então foram abordadas questões referentes a impactos sofridos pelas empresas, medidas tomadas, preparação para situações similares e estratégias para lidar e superar crises (Pforr e Hosie, 2008). No entanto, em seu estudo pós 11 de setembro, Prideaux (2004) afirmou que qualquer tipo de planejamento de contingência não aparecia na agenda operacional normal de várias empresas de turismo. Essa falta de planejamento foi observada não apenas no nível do operador individual, mas também no nível de agentes públicos locais (Ghaderi et al., 2012). Já na década de 2010, a pesquisa sobre recuperação de crises e desastres permaneceu relativamente silenciosa em relação às respostas aos desastres, sendo limitado o entendimento sobre as comunicações realizadas em tempos de crise entre partes interessadas (Mair et al., 2016). 
Mair et al. (2016), em sua revisão da pesquisa pós-desastre e pós-recuperação, incluindo desastres climáticos e pandemias, identificaram uma necessidade urgente de incentivar os operadores turísticos a se envolverem com estratégias de preparação para crises e gerenciamento de desastres de forma conjunta. Também foi identificada a importância de obter melhor compreensão da resposta do consumidor a estes eventos. No entanto, nos estudos, há poucas evidências que sugerem que os trabalhos em conjunto vêm ocorrendo. Contrariamente, foram identificadas falta de planos de gestão de crises, falta de comunicação e respostas reativas.

Jamal e Budke (2020), ao analisarem as lições de epidemias passadas para a pandemia do Covid-19 na literatura de turismo, examinam de que forma os eventos anteriores foram tratados e discutem ações e respostas propostas ao setor turístico durante a epidemia da síndrome respiratória aguda grave (SARS) e a epidemia do Ebola, visto que, neste período, vários pesquisadores de turismo pediram uma resposta proativa em termos de planejamento de gestão em tempos de crise (por exemplo, Mair et al., 2016). Entre os temas abordados estão: (i) necessidade de gerenciar a transmissão do vírus; (ii) necessidade de gerenciar o fluxo de informações com stakeholders; (iii) necessidade de gerenciar indivíduos em deslocamento por ocasião da eclosão da crise; e (iv) necessidade de cuidado com as comunidades nos destinos turísticos, em geral mais afetadas pela pandemia.

Por sua vez, Skare et al. (2021) observaram que pandemias como a causada pelo Covid-19 têm um impacto destrutivo muito maior na indústria de viagens e turismo do que estudos anteriores indicaram. Sendo assim, segundo Skare et al. (2021), os gerentes de turismo devem avaliar cuidadosamente os efeitos das epidemias nos negócios e desenvolver novos métodos de gestão de risco para lidar com a crise. 


\subsubsection{Respostas à crise: papel dos governos}

Os governos nacionais e locais são importantes agentes na contenção, gestão e recuperação de crises geradas por eventos críticos. No caso de pandemias, há inúmeros desafios na coordenação e compartilhamento de conhecimento durante e após uma crise, principalmente visando gerenciar a transmissão e disseminação de doenças infecciosas. Para alcançar os objetivos e desenvolver ações locais, o trabalho em conjunto entre agentes públicos e privados é fundamental, tanto no compartilhamento de conhecimento quanto na colaboração em atividades (Jamal e Budke, 2020; Mair et al.,2016).

As relações (relacionamento e confiança) entre autoridades turísticas, organizações e empresas devem ser ativamente estabelecidas através de uma comunicação consistente. Departamentos governamentais e organizações de turismo devem fornecer treinamento para as empresas locais aumentarem sua capacidade de gestão. Isso não é apenas importante para destinos turísticos que sofrem desastres naturais regulares, mas também quando se considera que a maioria dos negócios turísticos são pequenos e não dispõem de conhecimento e recursos para se prepararem com antecedência (Jiang e Ritchie, 2017).

Por essa razão, os governos devem exercer um papel de liderança na recuperação da indústria do turismo após um amplo desastre. Além do governo, as associações da indústria do turismo e os órgãos de marketing turístico devem estar ativamente engajados na gestão colaborativa de desastres, de modo a apoiar os interesses do turismo local e formar grupos de gestão de desastres que possam melhorar substancialmente o grau de envolvimento da indústria do turismo (Jiang e Ritchie, 2017).

Para tal, devem-se estabelecer ligações entre empresas de hotelaria e turismo, organizações de gestão de destinos e autoridades de saúde pública, visto que há forte dependência das autoridades locais de saúde para vigilância, monitoramento e tratamento das doenças associadas a pandemias. Para exercer as atividades, é 
necessário que tanto residentes locais quanto turistas e prestadores de serviços estejam bem informados, com base em fatos apresentados por autoridades de saúde confiáveis. Também é importante ter ética e cuidado com grupos marginalizados e excluídos devido a sua etnia, origem ou idade (Jamal e Budke, 2020). O apoio de políticas públicas e privadas precisa ser coordenado para garantir a capacitação e a sustentabilidade operacional do setor de turismo de viagens durante a pandemia (Skare et al., 2021).

Com relação a ações governamentais na pandemia do Covid-19, Sigala (2020) indica que a pandemia do Covid-19 levou governos a realizarem ações que limitassem a circulação de pessoas. Essa redução da mobilidade social teve fortes impactos no setor do turismo, fator que motivou os governos a atuarem de forma mais direta no setor. Para minimizar os impactos, fizeram dois movimentos: o primeiro consistiu na disponibilização de subsídios e incentivos fiscais. Além disso, foi necessário reestruturar as estratégias do setor para um foco em atividades dentro do próprio país, fator que levou o governo a realizar ações de infraestrutura logística, com o propósito de viabilizar esse novo formato de atuação, como, por exemplo, construção de aeroportos para atender a migração de linhas aéreas, antes internacionais, para serviços nacionais.

\subsubsection{Respostas à crise: papel das empresas}

As empresas têm papel importante no processo de recuperação pós-crise. Parte dessa preparação consiste em desenvolver respostas gerenciais a partir da formulação e execução dos processos de planejamento estratégico (Pforr e Hosie, 2008). O planejamento da gestão de crises e desastres mostra-se necessário para ajudar as partes interessadas no desenvolvimento de estratégias de prontidão e recuperação (Armstrong e Ritchie, 2008).A estratégia de marketing de recuperação pós-desastre precisa considerar tanto a natureza do desastre quanto o local onde ocorreu a crise. A resiliência de uma organização (ou destino turístico) pode ser impulsionada por sua capacidade de responder rapidamente a uma interrupção não prevista. Essa velocidade de resposta será resultado da construção da capacidade adaptativa e da redução de suas vulnerabilidades (Mair et al., 2016). 
Na busca de minimizar danos e maximizar oportunidades potenciais durante uma crise ou desastre em destinos turísticos, Mair et al. (2016) apontam alguns elementos interessantes no contexto do marketing. Com foco na recuperação, devese utilizar a comunicação informativa da crise ou desastre. Essas ações de comunicação visam recuperar a confiança e abrir oportunidade de diálogo com o consumidor de modo a que, no longo prazo, ele possa ser atraído de volta. De acordo com os autores, a literatura aponta três áreas principais onde a comunicação é vital - dos gestores aos stakeholders, entre as instituições turísticas e do destino turístico ao mercado. Walters e Mair (2012) salientam a importância de ações rápidas de marketing quando um destino é atingido por um desastre, visto que a imagem do destino é um fator de escolha importante por parte do turista. Nesse sentido, esforços de marketing de recuperação devem ser iniciados imediatamente para preservar a imagem do destino. Contudo, dada a necessidade de uma solução rápida, os profissionais de marketing geralmente agem sem buscar entender a provável resposta do público às mensagens veiculadas.

De maneira geral, a comunicação com os clientes é importante, principalmente na forma de informação e orientação para visitantes no destino por ocasião do evento disruptivo. Nesse contexto, Jamal e Budke (2020) destacam o papel da indústria turística no desenvolvimento de estratégias de comunicação em saúde, incluindo o fornecimento de orientação médica sobre a transmissão do vírus e medidas sensatas para reduzir o risco de infecção. Além disso, deve-se gerenciar a desinformação (Paraskevas et al., 2013) e garantir uma hospitalidade segura para os turistas. Dessa forma, identificar as informações apropriadas referentes a um destino atingido por um desastre ou crise e criar e transmitir mensagens adequadas através de estratégias de comunicação é fundamental na busca por recuperar a confiança do turista (Mair et al., 2016). Gani e Singh (2019) salientam que se concentrar no marketing de relacionamento como ferramenta de conscientização, colaboração e compartilhamento de conhecimento no setor de turismo também auxilia no planejamento de resposta a desastres. 
Para Castro e Zermeno (2020), um dos principais fatores responsáveis pela sobrevivência de pequenas e médias empresas está relacionado ao "espírito empreendedor". Em seu estudo, os autores revisaram como os empreendedores superam crises e os principais fatores relacionados a essa recuperação, a saber, a resiliência. Dentre os estudos analisados em sua revisão sistemática de literatura foram identificadas ações focadas em manter a fidelidade do cliente, atitudes próativas e otimismo, de forma a estabelecer um padrão responsivo para o enfrentamento das incertezas. Trazendo esses aspectos para a realidade da pandemia do Covid-19, esta incerteza pode ser vista também como uma oportunidade para as pequenas e médias empresas aproveitarem sua capacidade de adaptabilidade e flexibilidade para inovar, criar valor, diversificar produtos, renovar, reorganizar e até mesmo adotar novos modelos de negócios.

Com relação à pandemia do Covid-19, Sigala (2020) descreveu uma série de medidas tomadas inicialmente por empresas do setor de turismo com a intenção de minimizar os riscos de contaminação de funcionários, clientes e demais stakeholders, tais como: (i) mudanças no ambiente, através da instalação de equipamentos para higienização das mãos e utensílios; (ii) mudanças tecnológicas, na adoção de formas de pagamento sem contato, reservas, checkin e checkout online, trancas de portas sem contato e visitação online através de realidade virtual; (iii) mudanças de rotina, como por exemplo: escolhas de destinos com ambientes arejados, rotina de higienização e protocolos mais rigorosos; e (iv) mudanças de atividades, sendo realizadas para grupos menores, e evitando que sejam realizadas em ambientes compartilhados.

\subsection{Marketing de relacionamento como instrumento na gestão de crises e desastres}

Diferente da abordagem do marketing tradicional, no marketing de relacionamento considera-se que a função do marketing gire em torno do relacionamento, onde os objetivos das partes envolvidas são satisfeitos através de várias categorias de trocas, que ocorrem para estabelecer e fortalecer esses relacionamentos (Grönroos, 1990). É importante ressaltar a diferença entre lealdade e construção de relações com os consumidores. Esses dois termos devem ser tratados separadamente, especialmente 
no mercado consumidor de massa, pois os consumidores podem ser extremamente leais, mesmo que a organização não crie relacionamentos com eles (Cosic e Djuric, 2010).

O debate contemporâneo sobre o mercado turístico envolve uma releitura sobre o papel do marketing e do relacionamento com as partes interessadas, em especial com os clientes. Neste processo, o conceito de marketing de relacionamento, definido por Sheth et al. (2015) como "um processo contínuo de envolvimento em atividades e programas colaborativos com clientes imediatos e usuários finais para criar ou aumentar o valor econômico, social e psicológico de forma lucrativa", tem foco no desenvolvimento de relacionamentos de alta qualidade com consumidores. Dessa forma, seu uso está se tornando imperativo para a obtenção de benefícios e satisfação mútuos (Cosic e Djuric, 2010).

Embora alguns estudos tenham abordado o marketing de relacionamento, principalmente como resposta para o turismo em tempos de crise (Gani e Singh, 2019; Mair et al., 2016), a discussão sobre as razões que orientam essas iniciativas requer mais aprofundamento, sobretudo quando se trata do impacto do marketing de relacionamento para o alcance da recuperação de empresas de turismo no período pós-crise.

O marketing de relacionamento se destaca em dois aspectos principais: o maior grau de satisfação dos consumidores, por proporcionar um tratamento mais personalizado ao consumidor individual, relacionado à qualidade dos serviços prestados; e os efeitos sociais e financeiros, alcançados por meio de alianças estratégicas, em que novas oportunidades são criadas entre inúmeras empresas de turismo nos destinos turísticos. Essas duas dimensões são essenciais para o turismo, que precisa responder, concomitantemente, tanto às demandas de satisfação quanto às demandas sociais do setor (Cosic e Djuric, 2010).

Para que o marketing de relacionamento tenha sucesso, é necessário incentivar a lealdade entre os turistas através de uma cultura de cooperação, fornecendo e 
entregando valor aos turistas para, assim, construir um relacionamento de longo prazo (Fyall et al., 2003). Por essa razão, o marketing de relacionamento não é um fenômeno que pode ser confinado a um ou dois departamentos de uma organização, diferente do que era habitual no marketing tradicional. Toda a organização deve ser coordenada e cooperar para que os objetivos estabelecidos sejam alcançados. Isso é da maior importância quando se deseja que a função do marketing gire em torno do relacionamento com o cliente, em que os objetivos das partes envolvidas são satisfeitos por meio de várias categorias de trocas, que ocorrem para estabelecer e fortalecer esses relacionamentos (Fyall et al., 2003; Grönroos, 1990).

As principais ações dos canais de marketing do turismo tentam fazer com que os clientes retornem à mesma agência de viagens quando uma nova necessidade de compra lhes aparece e que recomendem a agência aos seus círculos sociais. As agências de viagens devem, portanto, tentar promover e nutrir o relacionamento com seus clientes e precisam conhecer os principais mecanismos que norteiam o comportamento de seus clientes (Moliner et al., 2007). Nesse contexto, é recomendado que as organizações mudem seu paradigma de comunicação, de respostas centradas em organizações para comunicações centradas no cliente/turista. Essa mudança permite que a empresa se concentre em auxiliar o público no enfrentamento da crise, além de facilitar interações e conversas entre a organização e o público (Jamal e Budke, 2020; Liu et al., 2016).

Walters e Mair (2012), em seu estudo, forneceram evidências de que as atividades de marketing devem prosseguir ao longo do período de recuperação de desastres, em particular, o marketing de relacionamento. Castro e Zermeno (2020), ao revisarem estudos empíricos, perceberam que os consumidores desempenham um papel importante na continuidade da empresa, não só através da fidelidade, mas também no relacionamento estabelecido através da solidariedade.

Steinhoff e Palmatier (2020) discutem sobre o marketing de relacionamento utilizando ferramentas tecnológicas nas práticas comerciais, dentre elas as mídias sociais. Os autores destacam a importância de utilizar as mídias sociais não só para promover a marca, mas também para realizar o monitoramento das reações do 
público-alvo buscando mitigar efeitos negativos e promover efeitos sociais positivos. No contexto do Covid-19, empresas utilizam redes sociais para estabelecer laços de solidariedade com seus clientes e observadores através da divulgação de ações sociais e comunitárias e fazendo uso de hashtags populares. Além disso, em decorrência da pandemia, os consumidores se mostram mais sensíveis a aspectos negativos e antiéticos por parte das empresas. Dessa forma, a pandemia ressaltou tanto os efeitos positivos, quanto as armadilhas das redes sociais para os profissionais de marketing, destacando, assim, a importância do uso do marketing de relacionamento nas relações digitais. 


\section{$3 \quad$ Metodologia}

Este capítulo apresenta as diversas decisões metodológicas para realização do estudo. Inicialmente, são apresentados o problema e as perguntas que orientaram a pesquisa. Em seguida, descreve-se o método de pesquisa utilizado (o estudo de caso), justificando-se sua adoção, dadas as características do estudo. Em seguida, detalham-se os métodos de coleta e análise dos dados. Por fim, são discutidas as limitações do método.

\subsection{Perguntas da Pesquisa}

Este estudo procurou investigar as reações de uma empresa brasileira de turismo, familiar e de pequeno porte, durante a pandemia do COVID- 19. Segundo Yin (2013), as perguntas de pesquisa têm sérias implicações para o restante do estudo de caso. Dessa forma, com o propósito de buscar um entendimento mais profundo de como pequenas empresas de turismo têm entendido, reagido e buscado soluções diante dos desafios ocasionados pela crise, as seguintes questões orientaram a pesquisa:

- Como os empreendedores em uma pequena empresa do setor de turismo perceberam a pandemia e seu impacto sobre o negócio ao longo do tempo?

- De que forma os empreendedores responderam à evolução da crise no que se refere à tomada de decisões? 


\subsection{Método da Pesquisa}

Optou-se por utilizar o método do estudo de caso para o desenvolvimento deste estudo, por ser considerado adequado à natureza e à complexidade do problema em questão, permitindo descrever os detalhes de uma situação, as percepções dos empreendedores e as decisões por eles tomadas em resposta à crise.

O estudo de caso é indicado em pesquisas que examinam um fenômeno contemporâneo em seu real contexto, principalmente quando as fronteiras entre o fenômeno e o contexto não são evidentes. Dessa forma, o estudo de caso pode utilizar múltiplas formas de recolhimento de dados, podendo combinar trabalho de campo, dados secundários, e observação do meio em que se encontra inserido o fenômeno, entre outros (Rowley, 2002; Yin, 1981, 2003).

A pesquisa de estudo de caso é um dos métodos mais populares usados pelos pesquisadores de marketing, tendo como principais unidades de análise as organizações, em situações de difícil acesso e estrutura complexa (Easton, 2010). Por ser uma abordagem que suporta uma investigação mais profunda e detalhada, normalmente busca responder a perguntas do tipo "como" e "por que", podendo oferecer insights que talvez não fossem alcançados com outras abordagens. Dessa forma, essas pesquisas costumam ser utilizadas posteriormente como base para o desenvolvimento de pesquisas quantitativas (Rowley, 2002). Considerando a especificidade e a atualidade do tema proposto no presente estudo, assim como o fato de existirem muitas lacunas a serem investigadas sobre o assunto, a abordagem do estudo de caso se mostra particularmente relevante.

Castro e Zermeno (2020), em sua revisão sistemática da literatura, ao analisarem os métodos utilizados em estudos sobre resiliência em tempos de crise, consideraram a pesquisa com métodos qualitativos com entrevistas em profundidade e estudos de uma abordagens metodológicas mais adequadas por permitir que novas pesquisas se aprofundem no assunto com foco nas experiências vividas pelos empreendedores. Além disso, os autores ressaltam que existem poucos estudos tratando da temática em países da América Latina. 
Optou-se por realizar um estudo de caso único. A opção por um caso único permitiu aprofundar o seu estudo, o que não seria possível caso se houvesse escolhido uma estratégia de múltiplos casos. O caso escolhido deveria atender aos seguintes critérios:

- Pertencer à indústria do turismo;

- Tratar-se de uma pequena empresa familiar brasileira;

- Que oferecesse apenas produtos de turismo nacional;

- Estar ativa durante a pandemia do COVID-19.

O caso da empresa Café e Viagens foi identificado como atendendo aos critérios anteriormente expostos. Além disso, a pesquisadora teve acesso à empresa, cujos empreendedores concordaram em conceder entrevistas ao longo da pandemia.

\subsection{Método de Coleta de Dados}

O presente trabalho utiliza tanto dados primários quanto dados secundários. Primeiramente realizou-se a coleta de informações sobre o setor turístico em fontes secundárias, entre as quais: dados de agências governamentais relativos às consequências do COVID-19 e ao setor; publicações em geral sobre o setor; e outras informações disponíveis na internet. A partir desses dados foi elaborado um roteiro para a realização das entrevistas exploratórias. Além disso, a pesquisadora participou de uma excursão curta conduzida pela empresa estudada, de modo a ganhar familiaridade com o negócio.

Entre abril e outubro de 2020 foram conduzidas entrevistas com os empresários responsáveis pela empresa Café e Viagens. As entrevistas foram realizadas com os dois empreendedores simultaneamente. Todas as entrevistas foram gravadas e transcritas, levando a um total de 214 páginas de transcrição. Posteriormente, foram solicitadas algumas informações complementares via contatos telefônicos e emails. A Tabela 3 apresenta uma relação das entrevistas realizadas, a data de 
realização e se foram conduzidas separadamente ou em conjunto. Todas as entrevistas foram conduzidas por meio virtual, utilizando a plataforma Zoom.

Tabela 3- Lista das entrevistas realizadas

\begin{tabular}{|l|l|l|}
\hline Data da entrevista & Entrevistados & Duração \\
\hline $18 / 04 / 2020$ & Ester e Daniel & $64^{\prime}$ \\
\hline $13 / 06 / 2020$ & Ester e Daniel & $109^{\prime}$ \\
\hline $16 / 07 / 2020$ & Ester e Daniel & 100, \\
\hline $01 / 10 / 2020$ & Ester e Daniel & 95, \\
\hline
\end{tabular}

Fonte: Autoria própria

\subsection{Análise de Dados}

Para análise dos dados coletados, fez-se inicialmente uma descrição detalhada do caso estudado, na qual se privilegiou a perspectiva temporal, delineando os eventos observados no período da pandemia e a visão dos entrevistados sobre os mesmos. Em seguida, foram identificados os estágios ao longo do período da pandemia analisado e, para cada estágio, foram definidas categorias observadas relativas a suas características, sentimentos expressos pelos empreendedores e respostas da empresa. Por fim, os achados da pesquisa foram confrontados com o referencial teórico utilizado, conforme sugerido por Yin (2013).

Além das entrevistas, e com o propósito de buscar a validade interna dos dados de natureza qualitativa, o percurso metodológico se pautou na triangulação dos dados (Vergara, 2005), tanto pelo fato de se fazerem entrevistas em diferentes momentos do tempo, como por se haver realizado uma observação participante no início do estudo. 


\subsection{Limitações do Estudo}

Há limitações que se referem ao método escolhido e outras limitações que são específicas do presente estudo.

Uma limitação característica do método do caso é em relação a sua capacidade de generalização. Por não obedecer aos critérios da lógica amostral de seleção dos casos, o método não permite generalização estatística. Dessa forma, os resultados aqui obtidos não devem ser estendidos a outras empresas além daquela em que foi realizado o estudo. No entanto, o método permite que se faça a generalização analítica. Assim sendo, é possível que os resultados obtidos ajudem a entender um certo tipo de pequena empresa, de perfil empreendedor, gerida pelos fundadores, em seu setor específico de atuação.

Além disso, a utilização de fontes primárias, como a entrevista em profundidade, está sujeita ao viés do entrevistado, já que suas respostas às perguntas abertas refletem suas percepções, mostrando sua visão pessoal em relação ao fato estudado. Além disso, pode estar sujeita a falhas de memória, ou ao viés de aprovação social. Uma abordagem para mitigar esse viés é combinar uma visão retrospectiva com observações em tempo real (Eisenhardt e Graebner, 2007). Segundo os autores, a realização de entrevistas e a observação do fenômeno em tempo real ajudam a mitigar o viés retrospectivo de criação de significados.

Ademais, a visão particular do pesquisador pode incorrer na formação do chamado viés do pesquisador, que influencia tanto a coleta de dados, quanto a análise posterior. Portanto, evitou-se, tanto quanto possível, tomar percepções e juízos de valor como fatos observados.

Observe-se, ainda, que o estudo não cobriu todo o período compreendido pela pandemia do Covid-19, dado que esta prossegue até a data de defesa desta dissertação. A coleta de dados foi encerrada em outubro de 2010 para que fosse possível concluir a análise de dados dentro dos prazos especificados. Saliente-se, porém, que a expectativa inicial era de que a pandemia chegasse a seu término bem 
antes do prazo de defesa. Apesar disto, acredita-se que o estudo traga uma efetiva contribuição ao conhecimento do tema. 


\section{Descrição do Caso: Café e Viagens}

Este capítulo apresenta o caso da empresa Café e Viagens, reunindo as informações levantadas, consideradas relevantes para o entendimento de sua atuação durante a crise ocasionada pela pandemia do COVID-19. Inicialmente, é apresentado um breve histórico da empresa, seguido da descrição de suas principais políticas de relacionamento com os clientes, princípios e valores, seu portfólio de passeios e sua estrutura. Por fim, descreve-se o seu posicionamento diante da pandemia e os resultados de sua gestão de crise obtidos até o momento atual.

\subsection{Histórico da Empresa}

No início de novembro de 2013 foi fundada a Café e Viagens, na capital do estado do Rio de Janeiro, pelo casal de empreendedores Ester e Daniel. Aliando a experiência de atendimento ao público de Ester e a experiência como motorista em excursões de Daniel, a Café e Viagens inicialmente apresentou-se como uma cafeteria com tema de viagens, localizada em Olaria (bairro de subúrbio do Rio de Janeiro). Através do contato com o público da cafeteria, a primeira excursão organizada pelos sócios teve aquele espaço como foco de divulgação. Daniel relatou:

"A Café e Viagens nasceu numa fase difícil. Como acontece com todo brasileiro, que começa com uma ideia nova numa fase difícil. Queríamos fazer alguma coisa para ganhar dinheiro. Pensamos primeiro em abrir uma loja. Conseguimos um espaço para alugar, mas ainda sem saber o que fazer. E pensamos no turismo, só não sabíamos como fazer. Com a ideia do turismo na cabeça, mas sem nenhuma experiência, no meu caso. Ele [Daniel] já tinha mais experiência como motorista, que é a profissão dele. Então a gente tentou conciliar o que ele sabia, e uma coisa que eu passei a gostar, como passageira de excursão. Eu cheguei a ir a algumas excursões com ele." (Ester)

"Eu tinha alugado uma lojinha ali em Olaria, perto da Estação de Olaria, para tentar fazer alguma coisa de lanche. Então veio a ideia de turismo, de começar alguma coisa com excursão também. Eu disse: 'Então vamos unir o útil ao agradável? Eu quero montar um Café e você quer montar um negócio de excursão, vamos fazer as duas coisas. E no Café vamos divulgar essas viagens. Organizamos duas viagens 
por ano para começar e vamos divulgar na loja. A loja coloca os cartazes, vai ser o ponto de divulgação.' Porque ainda não tinha nenhum cliente.” (Daniel)

A primeira excursão aconteceu entre 30 de novembro e 1 de dezembro de 2013, com destino a Conservatória, distrito do município de Valença, no estado do Rio de Janeiro. O local foi escolhido porque os empreendedores já haviam estado lá e reunia as condições ideais para uma primeira excursão:

"E agora, para onde vai ser? Um passeio que fosse barato, que fosse perto, porque a gente não tinha experiência. E um lugar que as pessoas pudessem se interessar, um local interessante, turístico. Aí nós nos lembramos de um hotel fazenda em Conservatória, que já conhecíamos e falamos 'vamos montar um passeio de final de semana para Conservatória, levar o pessoal para conhecer a cidade e ficar hospedado nesse hotel que é legalzinho, tinha uns chalés maneiros, tinha uma piscina boa e tudo o mais. E para quando a gente vai fazer? Ah, para o final do mês'. E só tinha 30 dias para divulgar. Então foi muito na cara e na coragem mesmo." (Daniel)

Paulatinamente, a partir da primeira excursão, de que participaram 23 clientes, ocorreu a "disseminação" (expressão utilizada por Daniel). Os primeiros clientes da empresa relataram de forma favorável a experiência a familiares e amigos, levando a que novos clientes se interessassem, o que veio a permitir, mais tarde, a realização da segunda excursão e de outras que se seguiram. Segundo relato dos sócios, alguns destes primeiros clientes se tornaram clientes regulares e participavam de excursões realizadas pela Café e Viagens até a época em que foram realizadas as entrevistas para este estudo.

A princípio, a segunda excursão seria em janeiro de 2014 com destino à região de Penedo (localizada no sul do estado do Rio de Janeiro), porém, foi adiada por número insuficiente de participantes. Foi então marcada uma nova data, no mês de junho, visando o público interessado em viajar no Dia dos Namorados. No entanto, a cafeteria passou por dificuldades, atribuídas à crise econômica que assolou o país, levando a que os empreendedores decidissem fechar a cafeteria ainda em abril, dedicando-se ao negócio de excursões. Neste contexto, os sócios decidiram começar uma página no Facebook e investir mais na divulgação da excursão a Penedo, que acabou por se realizar com sucesso em junho de 2014.

Nesta época, Ester recebeu uma oferta de trabalho interessante e decidiu tentar conciliar esta atividade com sua atuação na Café e Viagens. Apesar de terem 
decidido fechar a cafeteria, os empreendedores não queriam renunciar à empresa. Decididos a ter como foco as excursões, e para que a própria Ester pudesse atuar como guia, ela decidiu se profissionalizar. Com este propósito, matriculou-se em um curso para guia turístico. Em maio de 2015, Ester concluiu o curso e obteve o registro como guia no Ministério do Turismo. Desta forma, os empreendedores se tornaram aptos a cumprir todas as exigências legais e acompanhar as recomendações do setor, como destacado nos trechos a seguir:

"Eu não tinha noção desse mundo do turismo. Então, para mim foi tudo muito novo, eu tive que pesquisar muitas coisas. E ele [Daniel] falou: 'Você tem que fazer o curso de guia, porque, se temos uma empresa, legalizamos a empresa, ela tem CNPJ, tem alvará, tudo direitinho, você não pode estar conduzindo o grupo sem ser guia'.” (Ester).

“Até porque em algumas cidades não deixam o ônibus entrar com excursão se não tiver um guia profissional. [...] registrado no Ministério do Turismo. Então vimos a necessidade de ela ter essa formação como guia." (Daniel)

Para diferenciar sua oferta de outras agências e com o propósito de criar um vínculo especial com os clientes, os empreendedores passaram a oferecer, dentro do próprio ônibus, café da manhã completo, com bolo caseiro (feito pela própria empreendedora), chocolate quente, frutas, sucos etc. A partir de então, o café da manhã passou a ser não só um diferencial, como também a assinatura da empresa.

Com guia de turismo próprio e não mais necessitando contratar terceirizados, como ocorrera nas duas primeiras excursões, a Café e Viagens passou a oferecer uma média de três a quatro excursões por ano até 2017, sendo todas no estado do Rio de Janeiro. Podem-se citar como exemplos a Bauernfest em Teresópolis (cidade serrana do estado do Rio de Janeiro) e a excursão ao Parque Aquático Aldeia das Águas (em Barra do Piraí, município do Rio de Janeiro). Ester relatou:

"De 2015 para a frente, a gente ficou fazendo duas, três excursões no ano. E já pesquisando outras coisas e com alguns sonhos, né. A gente começou a ter o sonho de fazer uma excursão a Campos do Jordão que era um lugar que eu era louca para conhecer." (Ester)

Em julho de 2017 os empreendedores já haviam alcançado certa estabilidade financeira e uma clientela mais variada no que diz respeito ao interesse pelos destinos oferecidos. Colocaram, então, como meta realizar uma excursão por mês, meta que seria alcançada ainda naquele ano. Assim, em outubro de 2017 foi 
realizada a primeira excursão com duração de três dias, com destino a Conservatória, para o Carnaval Antigo, fora de época, sendo a excursão mais longa realizada até então. A partir daí os empreendedores montaram o calendário de 2018 com os eventos mensais. Foi então que notaram que a frequência dos passeios era um fator que ajudava, e não que atrapalhava, pois conseguiram ter uma rotatividade de clientes que atendia à oferta da empresa, fazendo com os clientes usuais passassem a procurar a Café e Viagens quando planejavam viajar em determinado mês.

Entendendo o resultado que a frequência de excursões gerava, os empreendedores decidiram que, mesmo quando não houvesse demanda suficiente para obter lucro em determinado passeio, faria sentido manter a excursão, desde que o resultado obtido permitisse arcar com os custos, ou seja, não gerasse prejuízo para o negócio. Isto porque, além de permitir uma demanda constante, manter a programação era importante para não gerar frustração no cliente que havia se planejado e criado expectativas com relação à viagem. Na verdade, os empreendedores tinham ouvido de clientes reclamações a esse respeito relativas a outras agências. Assim sendo, não desejavam trocar a divulgação boca-a-boca positiva sobre a excursão por uma divulgação negativa sobre um eventual cancelamento. Esta decisão se mostraria correta. Em 2018, das 12 excursões planejadas e realizadas pela empresa, apenas três não geraram lucro e as outras nove foram consideradas um sucesso.

Com o sucesso de um passeio por mês em 2018 e conseguindo realizar a tão sonhada viagem para Campos do Jordão, os empreendedores se propuseram um novo desafio para o ano seguinte, que se caracterizou por uma forte expansão dos negócios, como observou Ester: "Foi em 2019 que começamos a crescer”. Em 2019, foram planejadas e oferecidas duas excursões por mês, sendo uma de curta duração (um dia) e outra mais longa (quatro dias). Com uma clientela maior para os passeios de maior duração, a empresa conseguiu cumprir sua agenda de eventos durante todo o ano. Além disso, em alguns meses foram realizadas três excursões, sendo a terceira fechada para grupos exclusivos. Finalmente, em dezembro de 2019, os empreendedores tiveram seu maior desafio até então: uma excursão de Natal para a cidade de Gramado, no Estado do Rio Grande do Sul. Como relatado por Daniel: 
"Foi um grande desafio, o maior desafio de todo esse tempo, sendo também considerada uma das excursões mais trabalhosas que a empresa havia oferecido até então". E Ester reafirmou: "Foi um grande desafio o Natal Luz de Gramado, era uma excursão muito cara e muito trabalhosa para se organizar”.

A realização bem-sucedida de eventos mais complexos gerou uma valorização do portfólio da empresa, principalmente para quem acompanhava as redes sociais. Os sócios perceberam, então, que já estavam sendo vistos de maneira diferente no mercado: haviam passado de uma empresa que fazia passeios pequenos dentro do estado do Rio de Janeiro, para uma empresa que realizava excursões para todo o Brasil. Além disso, tendo atingido estabilidade financeira em decorrência da agenda com excursões recorrentes, Daniel decidiu adquirir seu próprio ônibus. Em fevereiro de 2020 começou uma nova sociedade, agora com seu irmão, onde realizaram a compra do ônibus e passaram a oferecer o serviço de aluguel de ônibus com motorista para a Café e Viagens. Daniel explicou o significado que o ônibus tinha para o negócio:

"Nós estávamos com excelentes perspectivas para esse ano de 2020, por conta do que foi 2019. Para a empresa foi muito bom. Então estávamos contando com duplicar em 2020. E aí apareceu a oportunidade de financiar o ônibus. Não é um ônibus novo, zero quilômetro, é já usado, mas é um ônibus muito bom. É de um fabricante, uma carroceria muito boa, muito confortável e com bastante recurso, assim, wi-fi, geladeira, tudo o que queríamos no nosso ônibus. Então o ônibus veio com isso tudo. E pensamos assim: 'Poxa, vamos comprar o ônibus, porque 2020 vai bombar, vai ser muito legal e vamos conseguir ganhar dinheiro com as viagens e também com o ônibus. Não vamos mais precisar ficar alugando ônibus, eu vou poder ir dirigindo em todas as viagens. Não vai ter mais esse negócio de se preocupar com o motorista que vem, o ônibus que vem. Então, foi a realização de um sonho." (Daniel)

\subsection{Situação antes da Pandemia}

Ao longo da trajetória da Café e Viagens, os empreendedores investiram tempo e esforços em ações de promoção de forma presencial, principalmente divulgando informalmente as atividades em diferentes grupos e situações, tanto nas próprias excursões, quanto fora delas. Quando as ações de divulgação aconteciam nos próprios passeios oferecidos, os empreendedores perceberam que a experiência do momento ajudava o cliente não só a comprar sua próxima viagens com a Café e 
Viagens, como também a convidar outros passageiros do grupo a participarem, como relatado por Ester:

"Falavam: 'Ah, você vai na outra? Porque a gente já faz a divulgação das outras excursões dentro da própria excursão que está acontecendo, porque assim eu pego a pessoa no calor da emoção de estar viajando na estrada, que vê o vídeo das próximas viagens. Às vezes a pessoa já sai dali com outra viagem fechada, já mais para frente. E já aconteceram viagens que, no final, eu tinha outras três ou quatro fechadas e até pagas com cartão.” (Ester)

As ações de divulgação antes das excursões ocorriam em diversos momentos. A empreendedora relata que sempre andava com os panfletos de divulgação buscando estar preparada para qualquer oportunidade, em aulas de ginásticas, filas de mercados, padarias, bares etc. E assim foi divulgando a empresa e construindo sua clientela, principalmente no início do negócio:

"Já aconteceu de estarmos no mercado fazendo compras e encontrar clientes no mercado. E eles falam assim: "Ester, estava te procurando, tem muito tempo que não te encontro e ... qual é a próxima excursão que tem? Eu quero ir." (Daniel)

Dentre muitas recomendações que o casal ouviu de conhecidos de dentro e de fora do setor sobre mostrar profissionalismo, ainda mais por se tratar de uma empresa familiar, uma delas era em relação ao horário de atendimento da empresa, sugerindo que fosse no horário comercial de segunda a sexta-feira. No entanto, diferente dessas recomendações, os empresários optaram por manter o horário flexível, fator que mais uma vez permitiu que aproveitassem diferentes oportunidades e atendessem demandas de diferentes grupos, com diversas rotinas. Daniel observou:

"O interesse é nosso de vender e, às vezes, as pessoas chegam cansadas do trabalho e só têm aquele tempo pra poder ver a questão da excursão que querem fazer no final de semana e não vão conseguir ligar pra gente no horário comercial." (Daniel)

O casal percebeu que a flexibilidade de horário de atendimento não só era um diferencial. Na verdade, seu produto deveria ser vendido aos finais de semana, aproveitando que muitas famílias se reúnem e confraternizam. Assim, o casal percebeu que era possível ser profissional e ter um horário diferenciado, entendendo que era no momento de lazer que seu produto de lazer podia ser mais facilmente vendido e utilizando o horário comercial para organização, planejamento, controle e procedimentos administrativos. Além de horário flexível, agenda de excursões com datas frequentes e prontidão para atendimento, o preço praticado se mostrava 
competitivo quando comparado com agências do mesmo porte da Café e Viagens, como relatado a seguir:

"Tem um outro rapaz que é guia também e faz excursão, e muitos clientes dele passaram pra gente. As excursões dele também são ótimas e sei que ele trabalha muito direitinho, e é um cara muito bacana. Mas nosso preço é melhor que o dele, então os clientes gostam mais do nosso preço e vão pela primeira vez pelo preço. Aí conhecem, gostam e ficam com a gente.” (Ester)

Com uma clientela ampla, em alguns dos passeios, a empresa conseguiu ocupar dois ônibus. Os empreendedores verificaram, então, que o cliente queria escolher o ônibus em que iria, e que essa escolha era determinada pelo ônibus em que a própria Ester iria, como observou uma cliente: "não, por favor não estou falando do ônibus, mas quero que seja com você". Isso fez com que os empreendedores decidissem revezar quem da equipe estaria em cada ônibus na ida e na volta das viagens. Com o crescimento da demanda e entendendo a preferência dos clientes por viajar com o casal estando presente, os sócios começaram a refletir sobre qual estratégia iriam optar: limitariam a quantidade de passeios ofertados para que ambos pudessem estar presentes ou se passariam a contratar outros guias e outras equipes mesmo sabendo que os clientes sentiriam essa diferença. A dúvida surgiu diante do medo da mudança gerar uma repercussão negativa para a empresa.

Os empreendedores reconheciam serem diferenciais o fato de ser uma empresa familiar, em que, a essa altura, trabalhavam o casal, a filha e a sobrinha, embora eventualmente também pudessem ter outros contratados. A relação pessoal com os clientes era vista por eles como muito importante para o sucesso do negócio, particularmente em relação aos clientes de Terceira Idade, que constituíam a grande maioria da clientela da empresa, e que "gostam muito de atenção, que você cuide deles", como observou Daniel.

\subsection{Impactos Iniciais da Pandemia nos Negócios da Empresa}

Em abril de 2020, um mês após a pandemia haver levado a uma quarentena, com fechamento temporário de diversos negócios, foi feita a primeira entrevista com os empreendedores. O impacto imediato que a empresa sofreu em consequência da 
pandemia foi em relação a sua agenda de viagens. Todo o resultado e experiências bem-sucedidas nos anos anteriores seriam repetidas em 2020, no entanto, precisaram ser adiadas ou canceladas. Como observou Ester: "Fizemos uma excursão a São Lourenço e ficamos no hotel Alzira, que é fantástico. Quando íamos novamente, agora, tivemos que cancelar por causa do coronavírus". Apesar dos imprevistos, os empreendedores mantiveram o foco no negócio e a esperança por momentos melhores, como observado na entrevista de abril de 2020:

"A gente continua com todo esse gás, eu praticamente estou aqui nessa quarentena e minha vida é pesquisar hotel para, assim que as coisas normalizarem, refazer o nosso calendário, porque algumas coisas eu cancelei, como por exemplo o hotel de São Lourenço, eu adiei o Barra Bonita... Algumas coisas que estavam programadas eu tive que adiar. Estamos aguardando as coisas voltarem ao normal para começar a relançar. Então, algumas coisas que já estavam prontas, programadas, eu vou só mudar a data, que para mim é até mais prático do que algumas coisas que eu ainda ia começar a negociar com os hotéis." (Ester)

Apesar da postura otimista, o cancelamento das viagens preocupou os empreendedores pelo fato de terem acabado de investir na compra do ônibus próprio:

"Eu comprei o ônibus dia 27 de fevereiro. Quando foi em março, na primeira ou segunda semana de março, veio a quarentena. Então o investimento ficou parado. O investimento ficou parado, as viagens não aconteceram, nós tivemos que arcar com todo esse prejuízo, todo esse custo, sem ter entradas. Foi muito difícil, infelizmente foi muito difícil. Mas a gente continuou acreditando que ia dar certo, que as coisas iam melhorar, que as coisas iam voltar ao normal. E fomos assim nos arrastando, fomos nos segurando onde deu, porque o turismo foi um dos setores muito abalados nessa pandemia." (Daniel)

Outra consequência da pandemia foi a redução dos contatos pessoais para divulgação das excursões. Mesmo assim, os clientes se mostraram interessados em, assim que possível, voltar a participar das excursões:

"Os clientes estão ligando, dizendo: 'ah, olha, quando isso tudo acabar, no primeiro passeio que você fizer, eu vou participar. O primeiro que você fizer, não importa para onde, já bota o meu nome! Que eu não aguento ficar em casa, eu quero sair'." (Daniel) 
Apesar do distanciamento físico, os empreendedores se preocuparam em estarem presentes, mesmo que virtualmente, na vida de seus clientes. Assim, neste primeiro momento da pandemia, a comunicação já não visava divulgar as excursões, que haviam sido adiadas, mas continha mensagens de apoio e esperança:

\begin{abstract}
"Eu tenho enviado mensagens perguntando como é que eles estão. Quando eu mando propaganda, nem todos respondem. Mas quando eu mandei uma mensagem querendo saber 'oi, como vocês estão', vários responderam. 'Oi, Ester, obrigada pelo seu carinho. Poxa, que bom falar com a família Café e Viagem'. Então, é esse carinho que a gente tem com eles. E $90 \%$ dos nossos clientes são idosos.” (Ester)

"Foi uma mensagem mesmo de preocupação, sincera, de como vocês estão, como é que está a vida de vocês, vamos ter esperança. Mandem notícias de como vocês estão, para a gente poder se unir numa campanha de esperança. Foi uma mensagem assim, e teve uma repercussão muito boa essa mensagem. Tivemos resposta de quase todos.” (Daniel)
\end{abstract}

\begin{abstract}
"Mandei mensagem assim: 'Quero saber como vocês estão. Nós aqui estamos nos cuidando, pausados e esperando esse tempo passar para estarmos juntos novamente e nosso encontros serão bem mais interessantes.' E outra mensagem assim: 'Vamos valorizar muito mais os nossos encontros quando a gente retomar, então esperem mais um pouquinho que vai dar certo"”. (Ester)
\end{abstract}

Estas ações obtiveram uma resposta além do que os empreendedores esperavam. Os clientes reagiram positivamente à demonstração de preocupação por parte do casal, como também se sentiram confortáveis em falar de suas angústias:

"Eles [clientes] mandam mensagens em áudio. Uma cliente conta que está deprimida e eu dou uma atenção especial. Não estou vendendo nada para eles, mas dou essa atenção. Ao que eu saiba, as empresas não fazem isso, a não ser empresas como a nossa, que são pequenas, que devem ter com certeza esse carinho com o cliente." (Ester).

No entanto, a duração da pandemia excedeu as expectativas iniciais. Por ocasião da segunda entrevista, em meados de junho de 2020, as atividades da empresa continuavam paralisadas. Nesta entrevista, os empresários focaram na história da empresa e em suas experiências passadas. O clima da entrevista foi de nostalgia:

"Agora à tarde nós estávamos vendo umas fotos, e começamos a ver uns vídeos. E eu falei: 'vamos postar uns vídeos na página para o pessoal começar a lembrar dos 
passeios e ter saudades'. Eu comecei a chorar. Eu falei: 'Que saudade que eu tenho disso!'. Então a gente hoje está saudoso. Sinto vontade de chorar só de falar." (Ester)

Mesmo assim, os empreendedores pretendiam fazer com que a empresa crescesse e se diversificasse:

"Temos projetos que talvez sejam interessantes, vamos entrar no aéreo e no marítimo... Promoção de eventos, cruzeiros. Vamos fazer algumas parcerias também. Fazer também cruzeiro com Café e Viagens. Era um plano para novembro de 2020, mas estamos adiando porque, de repente, não vamos conseguir diante de tudo isso. Então preferimos adiar para o próximo ano, mas já está nos nossos projetos entrar no turismo por ar e no mar." (Ester)

"Eventos de empresas, eventos empresariais... Estamos pensando em entrar nesse ramo no ano que vem. Eventos para igrejas também. Vamos organizar o transporte, o sítio para fazer conferências, o buffet... todo o operacional. É outro segmento, um negócio mais personalizado. [...] E aquelas pessoas que vão naquele evento nunca viajaram conosco." (Daniel)

A relação dos empreendedores com os clientes, baseada em relacionamento próximo e confiança, se mostrou bastante positiva. Em resposta à situação, alguns clientes, além de enviarem mensagens de preocupação, surpreenderam os empreendedores ao oferecer apoio financeiro caso estivessem precisando, como nos depoimentos dos empreendedores na terceira entrevista, em julho de 2020:

"Teve cliente que quis nos dar dinheiro porque sabia que, nessa pandemia, a empresa tinha parado. Essa pessoa perguntou: 'Ester, estou muito preocupada com vocês, em como vocês estão se virando e como é que vocês estão pagando as contas, porque não tem trabalho. Desculpe perguntar, fico muito sem graça de perguntar isso, mas estou muito preocupada com vocês. Se vocês estão precisando de alguma coisa, posso dar uma ajuda, para vocês se safarem esse mês. Não precisa devolver não, seria para ajudar, porque gosto muito de vocês, ou podem deixar de crédito para as próximas viagens'." (Daniel)

"Eu não aceitei, mas quase (risos). Achei melhor não aceitar... Ela insistiu: 'Olha, Ester, eu tenho o maior carinho por vocês, não me leve a mal não'. Ela falou muito sem jeito pra não nos ofender, eu agradeci muito, fiquei até emocionada, e falei para o Daniel: 'Isso me emociona, porque você vê que as pessoas têm realmente um carinho e não querem que a empresa feche. [...] Então, teve um retorno muito grande nesse período e isso foi muito legal." (Ester) 
A falta de suporte governamental foi também salientada como uma dificuldade a mais enfrentada pelos pequenos empreendimentos:

"E o Governo não disponibilizou recurso nenhum para o pessoal do turismo, nem para os autônomos, nem para as empresas. Somente as grandes empresas é que conseguiram usufruir de um recurso mínimo que o Governo disponibilizou. As pequenas empresas e os autônomos não conseguiram se beneficiar disso. Então foi muito, foi muito difícil.” (Daniel)

O contato constante com os clientes, que continuou no decorrer da pandemia, e as pesquisas pela internet de Ester mostraram alguns caminhos que poderiam ser trilhados pela empresa no decorrer da pandemia, enfatizando passeios próximos, sem hospedagem, em que o risco seria menor. Assim, os empreendedores começaram a planejar a retomada de atividades, sem esmorecer, como explicou Ester na entrevista de julho de 2020:

\begin{abstract}
"Programamos algumas atividades, até que eu percebi que os passeios mais longos não vão rolar, como o [parque] Beto Carreiro. Algumas pessoas mostraram interesse em reservar, mas eu não consegui a quantidade mínima, então provavelmente eu vou reagendar para o ano que vem. Mas a sugestão de todo mundo no meio do turismo é começar a explorar lugares mais perto, aqui no Rio, lugares mais próximos, passeios de um dia, porque as pessoas ainda estão com receio de ficar muitas horas no ônibus para viagens longas e ficarem em hotel. [...] As pessoas estão bem resistentes para viajar para longe, então vamos explorar coisas próximas para tirar o pessoal de casa, porque tem pessoas que querem sair, que já não aguentam mais. [...] O pessoal quer sair, mas não quer se expor. Então, divulgamos esse passeio do dia 15 que é em Cachoeira de Macacu, aqui pertinho, um parque florestal. E temos vinte e poucas pessoas interessadas, que já é a quantidade mínima atual no momento, porque tivemos que fazer uma redução de lotação do ônibus... E parece que, se Deus quiser, vai começar a melhorar... E vamos retomar com todas as mudanças do novo normal, com distanciamento dentro do ônibus, uso de máscaras, álcool em gel... As pessoas vão ficar mais distantes e as famílias vão ficar juntas. [...] Então, nesta retomada, vamos apostar em passeios curtos." (Ester)
\end{abstract}

\title{
4.3.1. Mudanças Realizadas no Decorrer da Pandemia
}

No segundo semestre de 2020 algumas cidades, incluindo o Rio de Janeiro, iniciaram o processo de flexibilização do isolamento social e com isso voltaram a 
aceitar a entrada de turistas. Com essa notícia, a empresa Café e Viagens retomou as atividades com muitas mudanças e em menor escala.

O retorno das atividades turísticas foi para o casal positivamente surpreendente. Apesar de contar com cerca de $90 \%$ de sua base de clientes do grupo de risco, a empresa conseguiu não só oferecer as primeiras excursões após seis meses sem operar, como também teve um bom retorno. A empresa conseguiu novos clientes e também atendeu a clientes já existentes:

\begin{abstract}
"A retomada foi super gratificante. Foi muito bom, porque sentimos que estava recomeçando. Estamos há seis meses sem poder trabalhar, sem saber o que fazer, imaginando como seria daqui para a frente. E o primeiro passeio [depois do início da pandemia] aconteceu, e não só aconteceu como foi divulgado. Porque uma coisa é você conseguir com os seus próprios clientes. Outra coisa é você ver que a ferramenta trabalhada, a divulgação, está funcionando. E aí você vê que as pessoas foram alcançadas, viram a divulgação e compraram o nosso produto. Então não foram só os nossos clientes que foram alcançados nesse recomeço. Nós conseguimos novos clientes também. Então isso para a gente foi bem legal porque, principalmente a Ester estava muito, muito desanimada sem saber como recomeçar, o que fazer. Então tudo isso foi bom, porque a gente viu que está funcionando novamente. (Daniel)
\end{abstract}

Ester salientou novamente o elo entre a empresa e seus clientes, que se manifestou de diversas formas durante a pandemia. Por ocasião da quarta entrevista, em outubro de 2010, com a retomada parcial de atividades, ela comentou:

"Percebemos que as pessoas ficaram muito felizes, 'que bom que vocês não fecharam as portas'. Eu senti isso. Porque muita gente fechou, muita gente faliu. Muita gente parou de trabalhar com turismo porque, no meu ponto de vista, foi um dos segmentos mais afetados, se não o mais. O setor de turismo e de eventos, de festas. Porque até hoje não reabriu. Muita coisa já reabriu há muito tempo, desde maio, desde junho. Mas, até hoje, tem cidades que não reabriram para o turismo. As viagens para fora do país também não voltaram, tem muito lugar que não está aceitando brasileiros. Então, eles [os clientes] ficaram felizes da empresa não ter desistido, fechado as portas." (Ester)

Com a volta das atividades, os empreendedores puderam, então, realizar o passeio de inauguração com o ônibus adquirido em fevereiro de 2020. Daniel ressaltou o orgulho e a satisfação envolvidos nessa conquista, assim como o trabalho de preparação envolvido durante o período sem atividades: 
A inauguração do ônibus foi no passeio de Cachoeiras de Macacu. Com isso, foi possível, pela primeira vez, sentir a satisfação, a alegria de ter adquirido o ônibus. Então, foi muito legal, as pessoas gostaram muito dele, se sentiram bem, se sentiram confortáveis, se sentiram seguras. E aí, sim, eu posso dizer que, nesse primeiro passeio, eu consegui me sentir realizando o meu sonho, de ter comprado o ônibus, de ter colocado ele lá na pista, de ter colocado meus clientes, meus passageiros nele, de eu poder ir dirigindo o meu próprio veículo. Então foi uma satisfação muito grande. Eu, na estrada, dirigindo e sabendo que aquilo ali era meu,. Foi muito gratificante, os passageiros elogiaram muito e torceram muito por isso, e estava lá sendo, sendo realizado. E nesse período de pandemia, eu aproveitei que o ônibus estava parado para ajeitar tudo o que precisava ser ajeitado nele, para colocar ele do meu jeito." (Daniel)

Os empreendedores haviam aproveitado os seis meses de pausa das atividades da empresa para fazer todas as adaptações necessárias para oferecer viagens seguras, cumprindo todos os protocolos de prevenção e combate à disseminação do coronavírus. Com toda a estrutura necessária, a empresa solicitou o selo de Turismo

Consciente e Turismo Responsável fornecido pelo Estado para as empresas comprometidas com a retomada de forma segura e investiu na divulgação da tão esperada inauguração do ônibus. E quando informados, os clientes reagiram positivamente, como relatou Ester: "Nossa, a gente quer ir, a gente quer conhecer o ônibus da Café e Viagens, o ônibus do Daniel”. Daniel explicou as mudanças que se fizeram necessárias:

"Então tivemos que ter todo um trabalho, uma logística diferente, propostas diferentes de viagem, dentro das novas normas de segurança contra o Covid-19. Tivemos que instalar kit com álcool gel no ônibus, tivemos que comprar produtos para higienização do ônibus, produtos específicos para o combate ao Covid. Investimos, compramos um termômetro para medir a temperatura das pessoas no ônibus, antes de entrar. Tivemos que comprar e distribuir máscaras para todos os nossos clientes, personalizadas, da Café e Viagens. E o kitzinho de luva e álcool gel. Enfim, fomos nos reestruturando." (Daniel)

Além de seguirem todos os procedimentos, os empresários se preocuparam em divulgar essas ações para tranquilizar e gerar mais confiança naqueles que desejavam realizar os passeios:

"Pensei: 'Vamos mostrar isso para os nossos clientes, o que estamos adquirindo, para ver se eles se sentem mais seguros para viajar.' Foi dando certo porque as pessoas que estavam querendo viajar, que estavam ansiosas e não sabiam como 
seria, nós as tranquilizamos um pouco. Então se sentiram um pouco mais seguras e vieram viajar com a gente." (Daniel)

Mesmo com a retomada das atividades, o fato de trabalhar com a capacidade de passageiros reduzida, para respeitar as normas de distanciamento social, impactou não só o preço cobrado, como também o lucro da empresa. Para arcar com todos os custos, levando um número menor de passageiros, os empreendedores não puderam manter os preços praticados antes da pandemia. No entanto, para que o impacto nos clientes fosse menor, a empresa diminuiu a margem de lucro e manteve o padrão de atendimento e serviço oferecido, a par das adaptações necessárias. Daniel descreveu os procedimentos adotados:

"Antes de eles [os passageiros] entrarem no ônibus, medimos a temperatura de cada um, depois pedimos para eles higienizarem as mãos com o álcool gel localizado na entrada do ônibus, do ladinho da porta. E dentro do ônibus, nós colocamos os passageiros distanciados, com uma distância de uma poltrona. E assim começamos a fazer. O café também foi servido sempre com luva, com máscara, com face shield e com pegadores. Tudo muito bem embalado, muito higienizado para o café da manhã. Tomamos muito cuidado com isso. Não deixamos de fazer porque o café da manhã no ônibus é a nossa marca. Percebemos que eles [os clientes] olharam a forma como estávamos fazendo, como estávamos trabalhando. Foi muito observado isso. Mas eles gostaram, eles disseram que se sentiram acolhidos. E elogiaram a nossa preocupação, toda a nossa adaptação." (Daniel)

Com a volta da confiança dos clientes em viajar, a empresa pôde contar com um bom retorno de reservas antecipadas para as primeiras excursões oferecidas na retomada das atividades, porém em uma escala menor quando comparado com a situação antes da pandemia. Este fato trouxe uma perspectiva positiva para os empreendedores que, mesmo tendo cancelado a agenda anterior, se preocuparam em adaptar os passeios e refazer o cronograma de destinos. Os empreendedores levaram em consideração aspectos como: duração da excursão, necessidade de hospedagem, tempo de locomoção, roteiro dos passeios, preferência por locais abertos entre outros, como salientado por Daniel:

\footnotetext{
"Muita gente não quer viajar para longe ou ficar muito tempo dentro de ônibus, então tivemos que optar por passeios mais próximos, lugares mais perto. Muita gente está com medo ou receoso de ficar hospedado em hotel. Então, pensamos em passeios sem hotel, sem hospedagem. Lugares, de preferência, ao ar livre. Para tudo isso tivemos que nos reinventar, tivemos que pensar em novas ideias. Restaurantes que a gente agendava, que eram restaurantes fechados, nós tivemos que trocar por
} 
restaurantes abertos, ao ar livre. Então refizemos a nossa agenda, pensamos em outros lugares, e colocamos tudo novamente para vender.” (Daniel)

Apesar de a retomada ter sido positivamente percebida pelos empresários, eles também enfrentaram algumas dificuldades. Uma das principais dificuldades foi em relação à estabilidade da agenda, pois muitas cidades mudavam o nível de restrição constantemente, tornando o cenário turístico incerto. "Nós montamos um pacote para Teresópolis, mas tivemos que cancelar porque estávamos na expectativa da cidade reabrir e eles não reabriram. E nós tivemos que cancelar esse pacote e tentar uma nova data". Além disso, as cidades que começaram o processo de retomada de turistas iniciaram com limitações e forte fiscalização, o que gerou longas filas de espera para marcar a visita ao local.

"Cada cidade está montando o seu programa de controle de acesso. As cidades que estão liberando, que estão abrindo de novo para o turismo, estão sendo rigorosas com os critérios. Então a gente tem que ligar para lá, tem que fazer agendamento antecipado, tem que informar qual o ônibus que está indo, o número, qual é a empresa, o motorista. Imagina, todo mundo que é guia, tudo o que é agência querendo fazer um passeio para Penedo, por exemplo, você liga para lá para agendar, você não consegue agendar porque tem um monte de gente na fila na sua frente." (Daniel)

Outros aspectos eram vistos com estranhamento, embora os empreendedores entendessem que havia um lado positivo. As reações dos clientes, nessas primeiras viagens quando a pandemia cedeu um pouco, no segundo semestre, foram inusitadas, e Ester relata algumas delas:

"Na verdade, são costumes diferentes que foram adotados para poder ter uma prevenção, diminuir a contaminação. Então, as cidades estão mais vazias, essa época já era para estar tudo muito cheio. Na nossa primeira excursão só estávamos nós lá. Então, assim, é bom e ruim ao mesmo tempo. O bom é que, assim, o lugar fica bem vazio. E é bom porque as pessoas estão muito diferentes, sensíveis. Gente que está com coragem para sair, mas que na hora você sente que a pessoa está apreensiva, toda hora passa um álcool. Como se estivesse se sentindo culpada. Então é esse sentimento que você percebe nas pessoas." (Ester)

"Eu observei também que algumas pessoas não queriam aparecer na foto com o grupo. Percebemos um comportamento de se esconder, principalmente por parte dos idosos: ' Porque meu filho não está me deixando sair. Eu saí escondido'. Outra cliente também falou assim 'ah, ainda bem que meu filho está não-sei-onde porque se ele sabe que eu estou saindo...'. Mudou, agora é o filho quem manda na mãe. (risos). Outros já dizem: 'ah, eu quero muito esse passeio, eu já estou surtando de ficar em casa, mas ainda estou com muito medo". Então você sente aquele desespero das pessoas. E tem gente que meteu a cara e saiu. Muita gente está 
tranquila, não quer nem usar máscara, o que eu não deixo: 'não, aí já é demais, bota a sua máscara, depois você se contamina, vai falar que foi no meu passeio, que foi na minha viagem'. Então, estamos percebendo um sentimento muito legal no primeiro passeio de agosto, quando as pessoas realmente saíram pela primeira vez. E aí resolveram sair e eu vi pessoas chorando porque estavam em um parque muito bonito, muita natureza, muito verde.” (Ester)

Os empreendedores também se defrontavam com as incertezas imediatas do negócio, particularmente a dificuldade de previsão dos meses seguintes. Ester explicou como as coisas estavam funcionando:

"Eu já estou começando a ter algumas ideias para janeiro, fevereiro e março, para começar a divulgar. Já tenho cliente, por exemplo, que já pagou metade da viagem de janeiro. Tem os dois extremos. Pessoas que já estão tranquilas, 'vamos viver a vida porque a gente vai morrer mesmo qualquer dia desses'. É assim que estão pensando. E outras que querem esperar. Isso traz aquele sentimento de incerteza, porque é tudo muito em cima da hora. [...] Eu fico pensando, não podia ser um pouquinho antes para eu não ficar tão estressada? Porque às vezes vem em cima da hora. Às vezes vem na última semana. E até esse último minuto eu estou sofrendo, porque faço as contas e a conta não fecha. Então, é um recomeço muito trabalhoso, e quem não tem disposição e quem também não tem fé, realmente não aguenta a pressão. Desiste mesmo. E dá para entender, porque é difícil. Mas, a expectativa é boa, estamos com planos para 2021, para as próximas excursões, já estamos animados para divulgar e fazer."

Apesar de todas as dificuldades e incertezas, os empreendedores comemoraram a vitória que consistiu no reinício de atividades, ainda que reconhecendo que tudo permanecia incerto, e era preciso "viver um dia de cada vez":

"Mas a sensação que tivemos foi de muita alegria, porque nem todo mundo conseguiu ainda botar um grupo no ônibus e fazer uma primeira viagem, mas nós conseguimos. Por outro lado, também ficamos um pouco receosos, porque o problema ainda está aí, o vírus ainda está aí. Temos responsabilidade, de certa forma, de levar as pessoas para fora de casa. Por mais que as pessoas sejam conscientes, vão porque querem, nós também nos sentimos muito responsáveis, de procurar lembrar as pessoas para terem os cuidados. [...] Mas está recomeçando. Devagarinho as coisas estão recomeçando. Estão reabrindo. E assim vamos vivendo um dia de cada vez, esperando as coisas normalizarem." (Ester)

\subsection{Situação da Empresa na Conclusão do Estudo}

Por ocasião da conclusão do estudo, a empresa estava com cinco excursões agendadas e divulgadas (Tabela 4) e outras em fase de elaboração e confirmação, sendo três delas de curta duração e duas com duração de mais de um dia. 
Tabela 4- Agenda divulgada pela Café e Viagens

\begin{tabular}{|l|l|}
\hline Destino & Data \\
\hline $\begin{array}{l}\text { Aldeia das Águas Park Resort - Barra } \\
\text { do Piraí (RJ) }\end{array}$ & Sábado, 16 de janeiro de 2021 \\
\hline São Roque - Festa da Uva & De 28 a 31 de janeiro de 2021 \\
\hline Ilhas tropicais - Itacuruça (RJ) & Sábado, 27 de fevereiro de 2021 \\
\hline Festa Cigana - São Lourenço & De 19 a 21 de março de 2021 \\
\hline Terra Santa & Sábado, 17 de abril de 2021. \\
\hline
\end{tabular}

Fonte: dados fornecidos pela empresa.

Uma das questões que se colocava aos empreendedores era a do crescimento, ou seja, como e até onde a empresa deveria crescer sem perder aquilo que eles viam como fonte principal de sucesso, a relação próxima, constante e amiga com os clientes. Ester expressou essa preocupação como se segue:

"Quando as pessoas viajam conosco e veem que o negócio é mais caloroso, mais família, mais acolhedor e mais informal - porque nós somos os donos, nós somos a empresa e nós estamos lá e cuidamos de tudo - então eles sentem essa diferença. Não que os outros [concorrentes] sejam ruins. Nem sempre são ruins, ao contrário, mas existe esse lance da empresa grande em que você tem que agir de acordo com as regras, padrão e tudo o mais. Mas conosco eles ficam mais à vontade, somos os donos e estamos lá, e, por esse motivo, nós conseguimos proporcionar um ambiente mais agradável para eles, mais informal, mais caloroso. Então tem esse diferencial, nós podemos proporcionar isso e a empresa grande não pode, porque a empresa grande não pode dar esse tipo de liberdade para todos os guias, cada guia com um temperamento diferente, com uma visão diferente. Ela [empresa grande] tem que criar um padrão e os guias têm que obedecerem àquele padrão porque senão perdem o controle da qualidade. Nós não, nós somos ao mesmo tempo donos e guia, então nós mesmos nos policiamos." (Ester) 
E prosseguiu:

"Eu tenho falado com o Daniel: vamos ter um problema se a empresa crescer - e queremos crescer, se Deus quiser - mas se a empresa chegar num patamar mais alto, como é que vamos fazer pra poder estar com eles... Por exemplo, eu vou vender uma excursão, mas vou ter que avisar: 'Olha, nessa não vou poder estar, porque nesse dia vou com outro grupo'. Será que eles vão querer ir? (risos) De repente, vai ter gente que vai falar: 'eu não quero ir, eu quero ir nesse outro em que você vai estar...' Isso acontece, isso é real.” (Ester)

Daniel complementou, explicando o dilema de crescimento que os empreendedores enfrentavam:

"Então, vai chegar num ponto que vamos ter que pensar. Ou vamos fazer todos os passeios e limitar a quantidade de passeios em que vamos poder estar presentes. A empresa vai limitar a quantidade de passeios em que a Ester e o Daniel vão participar e vão conseguir dar conta, ou vamos crescer a ponto de ter que colocar outros guias e outras equipes? Porque os clientes vão sentir essa diferença e pode ter uma repercussão ruim. Vai chegar uma hora em que vamos ter de optar por isso, entendeu, vamos chegar nessa encruzilhada: ou a empresa vai se manter naquele nível máximo [de atividades] que nós conseguimos executar, ou vamos crescer além daquilo?" (Daniel) 


\section{Discussão}

Este capítulo apresenta a análise dos resultados à luz da literatura examinada. Inicialmente faz-se uma breve análise da evolução da empresa. Em seguida examinam-se os estágios percorridos desde o início da pandemia até a data da conclusão do trabalho de campo.

\subsection{Evolução de um Pequeno Empreendimento e a Pandemia do Covid-19}

O caso da Café e Viagens proporciona uma oportunidade única para examinar de que forma a pandemia do Covid-19 impactou o processo de crescimento e consolidação de um pequeno empreendimento no setor de turismo. Para facilita essa compreensão, o Quadro 1 apresenta a evolução do empreendimento anterior à eclosão da pandemia.

Quadro 1- Evolução do Empreendimento

\begin{tabular}{|l|l|}
\hline Ano & Principais Eventos \\
\hline 2013 & $\begin{array}{l}\text { Criação da Café e Viagens, reunindo uma pequena cafeteria e um } \\
\text { negócio de excursões. Realização da primeira excursão pela empresa. }\end{array}$ \\
\hline 2014 & $\begin{array}{l}\text { Crise financeira, fechamento da cafeteria e passagem das atividades } \\
\text { para home office. }\end{array}$ \\
\hline 2015 & $\begin{array}{l}\text { Ester concluiu o curso de guia turística e obteve o registro no } \\
\text { Ministério do Turismo. }\end{array}$ \\
\hline
\end{tabular}




\begin{tabular}{|l|l|}
\hline 2016 & Maior investimento em divulgação \\
\hline 2017 & Primeira excursão interestadual \\
\hline 2018 & $\begin{array}{l}\text { Crescimento da empresa. Realização de uma excursão mensalmente e } \\
\text { elaboração do primeiro perfil de cliente. }\end{array}$ \\
\hline 2019 & $\begin{array}{l}\text { Continuidade do crescimento. Realização de duas excursões } \\
\text { mensalmente e elaboração do segundo perfil de cliente. }\end{array}$ \\
\hline 2020 & \begin{tabular}{l} 
Aquisição de ônibus próprio (fevereiro). \\
\hline
\end{tabular} \\
\hline
\end{tabular}

Fonte: Autoria própria.

O nascimento da Café e Viagens se deu de forma similar à de muitos outros pequenos empreendimentos, uma vez que a insatisfação com sua situação financeira e de carreira levou o casal a abrir uma empresa. Como os empreendedores tinham pouca disponibilidade de capital para investir e seus clientes tinham poucos recursos para gastar em lazer, os destinos iniciais eram próximos e de custo baixo. As atividades de marketing realizadas tanto por meio de uma página na plataforma Facebook e da divulgação presencial em pontos de encontro feita pela empreendedora em conjunto com sua capacitação como guia turística propiciou novas competências à empresa e permitiu não só a ampliação da base de clientes, viabilizando um portfólio mais variado, como também contribuiu para a ampliação do relacionamento com os clientes, o que os empreendedores acreditam ser um diferencial de seu negócio.

A expansão e consolidação do negócio ocorreu de forma mais significativa a partir de 2018. A experiência adquirida e o bom relacionamento com seus clientes permitiram que a empresa conhecesse o perfil de consumo e preferências dessa clientela, a maioria pertencente à Terceira Idade. A base de clientes se ampliava principalmente por meio de divulgação boca-a-boca e recomendações de clientes 
satisfeitos. Ao mesmo tempo, a empresa aumentava a oferta de viagens, tanto em número quanto em tipos diferentes. O ano de 2019, por fim, caracterizou o início de uma trajetória acelerada de crescimento, ultrapassado o período inicial de formação do negócio e de aprendizado, consolidando-se um modelo de negócio cuja principal vantagem diferencial era a oferta de excursões em ambiente familiar, com atendimento personalizado, realizado diretamente pelos donos da empresa, em que cada cliente era visto como um amigo, um parceiro e parte da família Café e Viagens.

Ao eclodir a pandemia, a empresa se encontrava no início deste processo de crescimento, que se esperava acelerado, apesar da recessão econômica enfrentada pelo país. Com a interrupção de atividades, os empreendedores, que tinham acabado de realizar um investimento significativo - a aquisição de um ônibus - se defrontaram com novas obrigações, mas sem a contrapartida de receitas.

\subsection{Estágios no Decorrer da Pandemia}

O início oficial da pandemia do Covid-19 no Brasil, com as medidas de confinamento, ocorreu em março de 2021. Foi possível reconhecer, a partir das entrevistas realizadas com os empreendedores, três estágios específicos por eles atravessados, do início da pandemia até outubro de 2020, quando se encerrou o trabalho de campo (Quadro 2).

Quadro 2- Estágios vividos pelos empreendedores no decorrer da pandemia e respostas da empresa

\begin{tabular}{|l|l|l|l|}
\hline Estágios & Características & Sentimentos & Respostas \\
\hline Interrupção & $\begin{array}{l}\text { Suspensão brusca de atividades } \\
\text { Expectativa de retorno } \\
\text { próximo }\end{array}$ & $\begin{array}{l}\text { Esperança } \\
\text { Inquietação } \\
\text { Comunicação rápida aos } \\
\text { clientes }\end{array}$ \\
\hline $\begin{array}{l}\text { Perda e } \\
\text { Resiliência }\end{array}$ & $\begin{array}{l}\text { Dificuldades financeiras } \\
\text { Planejamento de atividades } \\
\text { futuras }\end{array}$ & $\begin{array}{l}\text { Desânimo } \\
\text { Desamparo }\end{array}$ & $\begin{array}{l}\text { Comunicação aos clientes: } \\
\text { apoio }\end{array}$ \\
\hline
\end{tabular}




\begin{tabular}{|l|l|l|l|}
\hline Retomada & Reinício de atividades & Esperança & Turismo de proximidade \\
& $\begin{array}{l}\text { Planos para o futuro } \\
\text { Questionamentos }\end{array}$ & Alívio & Protocolos de saúde \\
Incerteza & $\begin{array}{l}\text { Adaptações operacionais } \\
\text { Selo Turismo Consciente } \\
\text { Comunicação informativa }\end{array}$ \\
\hline
\end{tabular}

Fonte: Autoria própria.

\subsubsection{Interrupção}

A pandemia do COVID-19 levou à suspensão brusca de atividades turísticas, sendo necessário o adiamento ou cancelamento de excursões que já estavam marcadas e com reservas vendidas antecipadamente. Dada a necessidade de uma resposta rápida, os empreendedores realizaram a comunicação da suspensão de atividades e enviaram mensagens de apoio aos clientes. Estas medidas estão de acordo com a recomendação de Walters e Mair (2012), de rápida comunicação com o público por ocasião de um evento disruptivo.

Com a expectativa de ocorrer um retorno relativamente breve das atividades, os empreendedores mantiveram "todo o gás", para reiniciar as atividades "assim que as coisas normalizarem", como observou Ester na primeira entrevista, em abril de 2020, um mês após o início da pandemia. A evidência de uma expectativa breve de retorno se fazia sentir, mas também a inquietação em virtude de terem assumido compromissos financeiros com a aquisição do ônibus.

\subsubsection{Perda e Resiliência}

À medida que os dias se passaram, a expectativa de um retorno das atividades foise tornando cada vez mais incerta, levando os empreendedores a enfrentarem muita incerteza quanto ao futuro dos negócios.

De forma a manter o relacionamento com os clientes, os empreendedores continuaram a enviar mensagens constantes, não mais promovendo as viagens, mas 
sim fazendo contato, pedindo notícias e levando palavras de esperança quanto à finalização da crise. As respostas a estas iniciativas surpreenderam os empreendedores. Alguns clientes aproveitaram o contexto da mensagem para fazer desabafos sobre as angústias trazidas pela pandemia, e alguns mostraram solidariedade com os empreendedores, oferecendo ajuda financeira ou mantendo o valor das viagens canceladas como crédito para viagens futuras. Esse apoio foi fundamental para a manutenção da esperança dos empreendedores, além da expectativa de um retorno próximo das atividades. De fato, os clientes são também parte interessada nos negócios da empresa e foram profundamente afetados pela interrupção de atividades, já que se travava de clientes de Terceira Idade, para os quais as viagens representavam um evento social importante para integrar-se socialmente e desenvolver atividades que frequentemente não puderam fazê-lo em fases anteriores da vida (Amaro, 2007). Também podem ter maior dificuldade para transferir uma viagem para o futuro, já que sua atividade turística sofre grande interferência dos eventos da vida, como nascimento de netos, doenças próprias ou de parentes etc. (Huber et al., 2019).

A comunicação de respostas centradas no cliente, ou seja, voltadas a auxiliar os clientes no enfrentamento da crise, foi um fator que os empreendedores consideraram muito relevante para o relacionamento da empresa com seu público, facilitando a interação e mantendo a lealdade. Este tipo de comunicação é recomendado na literatura como forma de abrandar os efeitos das crises que afetam o setor turístico (Jamal e Budck, 2020; Liu et al., 2016).

Apesar dos esforços para transmitir mensagens encorajadoras e manter o relacionamento com os clientes, os próprios empreendedores se sentiam desanimados, relatando sentimentos de nostalgia, que compartilhavam com os clientes. Termos como "saudades", "lembrar", "vontade de chorar", "pausar" ou “esperar" foram mencionados para explicar os sentimentos vividos nesta etapa.

À medida que a pandemia prosseguia e não se concretizavam as expectativas iniciais de volta às atividades turísticas, o quadro geral levava ao desânimo. Embora 
fossem esperadas ações governamentais mais diretas, na busca por minimizar os impactos sofridos pelo setor do turismo, estas não foram identificadas pelos empreendedores, diferente do indicado pela literatura, que aponta que a pandemia do Covid-19 levaria os governos a realizarem ações de reestruturação das estratégias do setor (Sigala, 2020). Jiang e Ritchie (2017) apontaram que grupos de gestão de desastres, apoiado por governos e outras instituições, poderiam melhorar substancialmente o grau de envolvimento da indústria do turismo, no entanto estas também não foram observadas. Este conjunto de fatores levou a uma sensação de desamparo, por se tratar de uma empresa pequena, que não dispunha dos conhecimentos e recursos necessários para lidar com este momento de pandemia. Os empreendedores estavam "sem trabalhar, sem saber o que fazer, imaginando como seria daqui para a frente".

No entanto, os empreendedores não desistiram, apesar da falta de apoio do governo, mas graças à solidariedade dos clientes e a sua própria resiliência. No decorrer da pandemia, continuaram planejando de que forma conduziriam os negócios quando fosse possível reabrir, inclusive com projetos de diversificação.

\subsubsection{Retomada}

Com a redução do número de casos e óbitos, no início do segundo semestre de 2020, os empreendedores passaram a se preparar para o reinício das atividades, introduzindo procedimentos que oferecessem menor risco aos clientes. De fato, como observam Pforr e Rosie (2008), no pós-crise os clientes do setor de turismo mostram-se particularmente sensíveis a riscos, sendo importante que as empresas estejam preparadas para proporcionar maior sensação de segurança, de forma a reduzir suas vulnerabilidades (Mair et al., 2016). Foi exatamente isso que a Café e Viagens fez. 
Em primeiro lugar, a adoção do chamado "turismo de proximidade" (Romagosa, 2020), já presente na literatura que fala da pandemia, foi uma das respostas planejadas pela empresa diante da nova situação, em que a pandemia havia cedido, sem, no entanto, terminar. Assim sendo, a empresa redesenhou o produto oferecido - viagens de um dia, sem hospedagem. Em segundo lugar, os empreendedores realizaram adaptações seguindo os protocolos de saúde para redução de transmissão do vírus, medidas que estão de acordo com a recomendação de Pforr e Hosie (2008) para a redução da percepção de risco pessoal de potenciais clientes. As adaptações incluíram a instalação de equipamentos para higienização de mãos e utensílios, medidores de temperatura e placas com orientações para a minimização da disseminação do vírus. Além disso, adotaram normas de distanciamento social. Finalmente, comunicaram aos clientes, por meio das mídias sociais, as adaptações realizadas, os selos obtidos de turismo consciente e responsável e os novos procedimentos e normas adotados pela empresa. Esta comunicação informativa, observada em estratégias de marketing de recuperação pós-crise, pode abrir oportunidades de diálogo com o consumidor (Mair et al., 2016), o que, de fato, trouxe resultados satisfatórios para a empresa. Além disso, evidenciavam o comprometimento da empresa com a saúde de seus clientes.

Diversas dificuldades continuavam se colocando. Os empreendedores sinalizaram o impacto negativo decorrente do fechamento de fronteiras, inclusive em nível municipal, assim como de restrições à mobilidade local, fatores que inviabilizam a realização das atividades turísticas, inclusive de excursões. Mudanças súbitas na liberdade de deslocamento para cidades turísticas, em função das tendências de crescimento da pandemia, ou de surtos locais, levavam a modificações de agenda, cancelamentos e desgaste, mas os empreendedores reconheciam ter que lidar com essas dificuldades. A previsibilidade quanto ao número de clientes também foi afetada, já que as pessoas poderiam marcar ou desmarcar de última hora uma viagem em função de situações pessoais relacionadas à pandemia. De fato, como sugeriram vários autores (Koch et al. 2020; Sheth, 2020; Sigala, 2020; Romagosa, 2020), os empreendedores constataram mudanças nos comportamentos dos clientes, mudanças essas que tanto poderiam se manter no futuro, quanto serem momentâneas, ou seja, apenas um resultado imediato da pandemia. 
Os empreendedores optaram ainda por investir em novas estratégias de divulgação, especialmente através das redes sociais, buscando atrair a atenção de clientes de diferentes faixas etárias. Essa decisão levou em consideração a predominância de idosos em sua base de clientes, que, por compor um grupo potencial de risco na pandemia, vivenciam interferência familiar nas suas decisões.

A retomada de atividades da empresa foi considerada pelos empreendedores como "super gratificante", particularmente pela boa receptividade dos clientes, muitos dos quais se engajaram nos passeios curtos realizados pela empresa. No entanto, ainda assim os empreendedores lidavam com elevado grau de incerteza em relação ao futuro. 


\section{Considerações Finais}

A pandemia do Covid-19 caracterizou-se pela imprevisibilidade no que se refere às suas dimensões: geográfica, estendendo-se a todos os continentes e países; econômica, pela suspensão de atividades produtivas em todo o mundo, ruptura de cadeias de suprimento globais e fechamento, temporário ou definitivo, de número imenso de empresas em todo o mundo; e social, por levar a uma escalada do desemprego e lançar número incontável de famílias na miséria. Assim, a crise de que tratou este estudo combina vários tipos de risco, como destacaram Castro e Zermeno (2020). Em particular, a indústria do turismo apresenta alta exposição a riscos oriundos de eventos disruptivos (Sigala, 2020), e a pandemia do Covid-19 não se constituiu em exceção, atingindo duramente o setor. Foi neste contexto que se buscou estudar como a crise impactou um pequeno negócio familiar e quais as respostas dadas pelos empreendedores face à pandemia.

O estudo utilizou a escassa literatura que trata dos impactos de eventos disruptivos no setor de turismo, além de recorrer à literatura de marketing de relacionamento como recurso para a gestão de crises nas empresas. $\mathrm{O}$ método adotado foi o estudo de caso único, longitudinal, de uma pequena empresa empreendedora. Os dados foram obtidos por meio de entrevistas pessoais com os empreendedores.

\subsection{Conclusões}

Embora o método adotado não permita generalizações para a população, o estudo trouxe respostas às perguntas de pesquisa inicialmente colocadas, gerando subsídios para futuras pesquisas que investiguem eventos disruptivos no turismo.

O estudo mostrou que, no decorrer de uma pandemia, as percepções dos empreendedores vão se alterando, à medida que os eventos descortinam diferentes 
tendências. Os empreendedores respondem de forma distinta em vários momentos da crise, adaptando-se às circunstâncias e focando seus esforços no relacionamento com os clientes, principal ativo de sua empresa. Espírito empreendedor, resiliência, adaptabilidade e flexibilidade se mostraram fundamentais no enfrentamento da crise ocasionada pela pandemia do Covid-19.

Os resultados do estudo mostraram ainda o potencial dos instrumentos de marketing de relacionamento para fazer frente a eventos disruptivos no setor de turismo, fazendo com que os clientes recorram à mesma agência de viagens (ou outro operador turístico) e que recomendem a empresa a suas redes sociais (Moliner et al., 2007). Neste setor, a divulgação boca-a-boca é fundamental para o sucesso do empreendimento. Além disso, trata-se de um marketing interativo, em que tanto a empresa se comunica com os clientes, quanto esses respondem à empresa, fornecendo e entregando valor de forma mútua (Fyall et al., 2013). Os clientes podem exercer um papel importante na continuidade da empresa, não só pela fidelidade, como também pela solidariedade (Castro e Zermeno, 2020), podendo ter impacto fundamental na manutenção do otimismo e da resiliência dos empreendedores.

Com relação ao papel do governo, um dos temas tratados na literatura examinada (Jamal e Budke, 2020; Mair et al., 2016), não se observou o exercício de um papel de liderança pelas várias esferas governamentais (municipal, estadual ou federal), não só pela ausência de treinamento para melhorar a capacidade de gestão, mas também pela falta de políticas públicas (Skare et al, 2021), tais como as que envolvem a concessão de subsídios e incentivos fiscais (Sigala, 2020). A criação governamental dos selos Turismo Consciente e Turismo Responsável tiveram o intuito de passar mais credibilidade às empresas do turismo em relação ao combate à disseminação do vírus. No entanto, os empreendedores informaram não haver uma verificação do cumprimento das recomendações por parte dos órgãos governamentais, cabendo aos próprios clientes a missão de denunciar a empresa, caso não aja em conformidade com as recomendações. 


\subsection{Sugestões e recomendações para novas pesquisas}

O papel do marketing de relacionamento pôde ser claramente observado neste estudo de caso, no entanto, dado que a pandemia ocasionada pelo Covid-19 continuava em andamento por ocasião da conclusão desta dissertação, caberá a pesquisas futuras avaliar o impacto do marketing de relacionamento para o alcance da recuperação de empresas de turismo pós-crise.

Como desdobramentos futuros, essa pesquisa pode ser estendida através de investigação sobre as mudanças de comportamento e preferência dos consumidores de atividades turísticas. A literatura indica que essas mudanças podem estar relacionadas às consequências da pandemia, tais como: crise na saúde, crise econômica, restrições de mobilidade social e fechamento de fronteiras (Romagosa, 2020). Em relação às mudanças no comportamento do consumidor, a questão da sustentabilidade das atividades turísticas vem ganhando destaque (Romagosa, 2020). Mohanty et al., (2020) sugerem alternativas como turismo virtual através de realidade aumentada como opções alternativas ou complementares às atividades turísticas. Além disso, Seraphin e Dosquet (2020) argumentam que o turismo de segunda residência (casa de montanha e veraneio) venha a ser a alternativa preferencial do consumidor. No entanto, esses aspectos não puderam ser verificados de forma empírica no presente estudo, cabendo a pesquisas futuras explorarem esses temas, que permanecem em aberto. 


\section{$7 \quad$ Referências Bibliográficas}

AMARO, LUIZ EDUARDO; JOHANN, JORGE RENATO; MEIRA, PAULO RICARDO. O estilo de vida do idoso urbano: o caso de Porto Alegre-RS. Revista Brasileira de Ciências do Envelhecimento Humano, v. 4, n. 1, 2007.

ARAUJO, FÁBIO FRANCISCO. Significados do Lazer na Terceira Idade: Um Estudo Interpretativo de Grupos de Seresta e Dança de Salão. 2015. Tese de Doutorado. PUC-Rio.

ARMSTRONG, E. KATE; RITCHIE, BRENT W. The Heart Recovery Marketing Campaign. Journal of Travel \& Tourism Marketing, 23:2-4, 175-189, 2008.

BARNHART, M.; PEÑALOZA, L. Who Are You Calling Old Negotiating Old Age Identity in the Elderly Consumption Ensemble. Journal of Consumer Research, v. 39, n.6, p. 1133-1153, 2013.

BRASIL . Turismo brasileiro cresce 2,6\% em 2019. 2020a. Disponível em:

<https://www.gov.br/pt-br/noticias/viagens-e-turismo/2020/01/turismo-brasileirocresce-2-6-em-2019> Acesso em: 29/10/2020

BRASIL. Anuário Estatístico de Turismo 2020 - Ano Base 2019 - $2^{\text {a }}$ edição. 2020b. Disponível em: <http://www.dadosefatos.turismo.gov.br/> Acesso em: $29 / 10 / 2020$

BRASIL. Boletim Epidemiológico Especial. 2020c. Disponível em: <https://www.gov.br/saude/ptbr/media/pdf/2020/outubro/23/boletim_epidemiologico_covid_36_final.pdf> Acesso em: 30/11/21 
CASTRO, MAY; ZERMEÑO, MARCELA GEORGINA. Being an entrepreneur post-COVID-19 - resilience in times of crisis: a systematic literature review. Journal of Entrepreneurship in Emerging Economies, 2020. https://doi.org/10.1108/JEEE-07-2020-0246

COSIC, MAJA; DJURIC, MILENKO D. Relationship marketing in the tourist services sector, UTMS Journal of Economics, ISSN 1857-6982, University of Tourism and Management, Skopje, Vol. 1, Iss. 1, pp. 53-60. 2010.

DANTAS, G et al. The impact of COVID-19 partial lockdown on the air quality of the city of Rio de Janeiro, Brazil. Science of the Total Environment 729, 2020. https://doi.org/10.1016/j.scitotenv.2020.139085

EASTON, GEOFF. Critical realism in case study research. Industrial Marketing Management 39, p 118-128, 2010.

EISENHARDT, KATHLEEN M.; GRAEBNER, MELISSA E. Theory building from cases: Opportunities and challenges. Academy of management journal, v. 50, n. 1, p. 25-32, 2007.

FARZANEGAN, MOHAMMAD REZA; GHOLIPOUR, HASSAN F.; FEIZI, MEHDI; NUNKOO ,ROBIN; ANDARGOLI, AMIR ESLAMI. International Tourism and Outbreak of Coronavirus (COVID-19): A Cross-Country Analysis. Journal of Travel Research, 2020.

FONTOURA, L.; LUSBY, C.; ROMAGOSA, F. Turismo Pós-COVID-19: Perspectivas para o Turismo Sustentável no Brasil, Estados Unidos E Espanha. Revista Acadêmica do Observatório de Inovação do Turismo, v. 14, n. Especial, p. 16-28, 2020. 
FOO, LEE-PENG; CHIN ,MUI-YIN; TAN, KIM-LENG \& PHUAH, KIT-TENG. The impact of COVID-19 on tourism industry in Malaysia. Current Issues in Tourism, 2020. DOI: 10.1080/13683500.2020.1777951

FYALL, ALAN; CALLOD, CHRISTINE; EDWARDS, BRENDA. Relationship marketing: The Challenge For Destinations. Annals of Tourism Research, Vol. 30, No. 3, pp. 644-659, 2003.

GALVANI, ADRIANA; LEW, ALAN A.; PEREZ, MARIA SOTELO. COVID-19 is expanding global consciousness and the sustainability of travel and tourism, $\begin{array}{llll}\text { Tourism } & \text { Geographies, } & 22: 3, & 567-576,\end{array}$ DOI:10.1080/14616688.2020.1760924

GANI, ABDUL; SINGH, RAMJIT. Managing Disaster and Crisis in Tourism: A Critique of Research and a fresh Research Agenda. African Journal of Hospitality, Tourism and Leisure. Volume 8 (4), 2019.

GHADERI, Z., MAT SOM, A. P., \& HENDERSON, J. Tourism, crises, and island destinations: Experiences in Penang, Malaysia. Tourism Management Perspectives, 2-3, 79-84. 2012.

GOLDANI, A.M. "Ageism" in Brazil: What is it? Who does it? What to do with it? R. bras. Est. Pop., Rio de Janeiro, v. 27, n. 2, p. 385-405, jul./dez. 2010

GRONROOS, CHRISTIAN. Relationship Approach to Marketing in Service Contexts: The Marketing and Organizational Behavior Interface. Journal of Business Research 20, 3-11, 1990. 
GÖSSLING, STEFAN; SCOTT, DANIEL; HALL, MICHAEL. Pandemics, tourism and global change: a rapid assessment of COVID-19. Journal of Sustainable Tourism, 29:1, 1-20, 2021. DOI: 10.1080/09669582.2020.1758708

HAMMERSCHMIDT KS de A, SANTANA RF. Saúde do idoso em tempos de pandemia Covid-19. Cogitare enferm. 2020. Acesso em: 22/10/2020. Disponível em: http://dx.doi.org/10.5380/ce.v25i0.72849.

HOPKINS, J. University of Medicine. Coronavirus Research Center, 2020. Disponível em: <https://coronavirus.jhu.edu/map.html> Acessado em 20 de outubro de 2020.

HORTON, P. B.; HUNT, C. L.. Sociologia. [s.l: s.n.]. 1981.

HUBER, Dominik; MILNE, Simon; HYDE, Kenneth F. Conceptualizing Senior Tourism Behaviour: A Life Events Approach. Tourist Studies, v. 19, n. 4, p. 407433, 2019

IRVING, M. A.; COELHO, A. M.; ARRUDA, T. O. Turismos, Sustentabilidades e Pandemias: Incertezas e Caminhos Possíveis para Planejamento Turístico no Horizonte da Agenda 2030. Revista Acadêmica do Observatório de Inovação do Turismo, v. 14, n. Especial, p. 73-105, 2020.

JAMAL, T.; BUDKE, C. Tourism in a world with pandemics: local-global responsibility and action. Journal of Tourism Futures, 2020.

JIANG, Y.; RITCHIE, B. W. Disaster collaboration in tourism: Motives, impediments and success factors. Journal of Hospitality and Tourism Management, v. 31, p. 70-82, 1 jun. 2017. 
KAUSHAL, VIKRANT; SRIVASTAVA, SIDHARTH. Hospitality and tourism industry amid COVID-19 pandemic: Perspectives on challenges and learnings from India. International Journal of Hospitality Management 92, 102707, 2021. https://doi.org/10.1016/j.ijhm.2020.102707

KOCK, FLORIAN; NØRFELT, ASTRID; JOSIASSEN, ALEXANDER; ASSAF, A. GEORGE; TSIONAS, MIKE G.; Understanding the COVID-19 tourist psyche: The Evolutionary Tourism Paradigm, Annals of Tourism Research, Volume 85, 103053, 2020. https://doi.org/10.1016/j.ijhm.2020.102707

KOH, E., "The end of over-tourism? Opportunities in a post-Covid-19 world", International Journal of Tourism Cities, Vol. 6 No. 4, pp. 1015-1023, 2020. https://doi.org/10.1108/IJTC-04-2020-0080

LAPOINTE, DOMINIC. Reconnecting tourism after COVID-19: the paradox of alterity in tourism areas. Tourism Geographies, 22:3, 633-638, 2020. DOI:10.1080/14616688.2020.1762115

LIU, BINGJIE; PENNINGTON-GRAY, LORI; KRIEGER, JANICE. Tourism crisis management: Can the Extended Parallel Process Model be used to understand crisis responses in the cruise industry? Tourism Management 55, 310-321, 2016.

MAIR, JUDITH; RITCHIE, BRENT W.; WALTERS, GABBY. Towards a research agenda for post-disaster and post-crisis recovery strategies for tourist destinations: a narrative review, Current Issues in Tourism, 19:1, 1-26, 2016. DOI: $10.1080 / 13683500.2014 .932758$

MANGIALARDO, JOSÉ ET AL. Políticas Públicas De Turismo No Brasil: Dinâmicas Sociais E Regionalização. Revista Diálogos Interdisciplinares VOL. $8 \mathrm{~N}^{\circ} 4,2019$. 
MARQUES, ROSEANE BARCELLOS; ALVES, CARLOS ALBERTO; WADA, ELIZABETH KYOKO. Turismo e Corrupção no Brasil: uma perspectiva política e econômica. Revista Turismo em Análise - RTA | ECA-USP | v. 31, n. 1, p. 1-18, jan./abr., 2020. DOI: http://dx.doi.org/10.11606/issn.1984-4867.v31i1p1-18

MOHANTY, P; HASSAN, A; EKIS, E. "Augmented reality for relaunching tourism post-COVID-19: socially distant, virtually connected", Worldwide Hospitality and Tourism Themes, Vol. 12 No. 6, pp. 753-760, 2020. https://doi.org/10.1108/WHATT-07-2020-0073

MOLINER, MIGUEL A.; SÁNCHEZ, JAVIER; RODRÍGUEZ, ROSA M.; CALLARISA, LUÍS. Relationship quality with a travel agency: The influence of the postpurchase perceived value of a tourism package. Tourism and Hospitality Research, Vol. 7, 3/4, 194-211, 2007.

PARASKEVAS, ALEXANDROS; ALTINAY, LEVENT; MCLEAN, JACQUELINE; COOPER, CHRIS. Crisis Knowledge In Tourism: Types, Flows And Governance; Annals of Tourism Research, Vol. 41, pp. 130-152, 2013. http://dx.doi.org/10.1016/j.annals.2012.12.005

PFORR, CHRISTOF; HOSIE, PETER J.CRISIS Management in Tourism, Journal of Travel \& Tourism Marketing, 23:2-4, 249-264, 2008. DOI: 10.1300/J073v23n02_19

PRIDEAUX, BRUCE; LAWS, ERIC; FAULKNER, BILL. Events in Indonesia: exploring the limits to formal tourism trends forecasting methods in complex crisis situations. Tourism management 24, 475-487, 2003. doi:10.1016/S02615177(02)00115-2 
PRIDEAUX, BRUCE. The Need to Use Disaster Planning Frameworks to Respond to Major Tourism Disasters, Journal of Travel \& Tourism Marketing, 15:4, 281298, 2004. DOI: 10.1300/J073v15n04_04

QIU ,RICHARD T.R.; PARK, JINAH; LI, SHINA; SONG, HAIYAN. Social costs of tourism during the COVID-19 pandemic. Annals of Tourism Research 84, 102994, 2020. https://doi.org/10.1016/j.annals.2020.102994

RITCHIE, BRENT W. Chaos, crises and disasters: a strategic approach to crisis management in the tourism industry. Tourism Management, 25, 669-683, 2004. doi:10.1016/j.tourman.2003.09.004

ROMAGOSA, FRANCESC. The COVID-19 crisis: Opportunities for sustainable and proximity tourism. Tourism Geographies, 22:3, 690-694, 2020. DOI:10.1080/14616688.2020.1763447

ROWLEY, JENNIFER. Using Case Studies in Research. Management Research News, Volume 25, Number 1, 2002.

SERAPHIN, H.; DOSQUET, F. "Mountain tourism and second home tourism as post COVID-19 lockdown placebo?", Worldwide Hospitality and Tourism Themes, Vol. 12, No. 4, pp. 485-500, 2020.

SHETH, JAGDISH. Impact of Covid-19 on consumer behavior: Will the old habits return or die?, Journal of Business Research, Volume 117, Pages 280-283, 2020. https://doi.org/10.1016/j.jbusres.2020.05.059.

SHETH, J. N., PARVATIYAR, A., \& SINHA, M. The conceptual foundations of relationship marketing: Review and synthesis. Journal of Economic Sociology= Ekonomicheskaya sotsiologiya, 16(2), 119-149, 2015. 
SIGALA, MARIANNA. "Tourism and COVID-19: Impacts and implications for advancing and resetting industry and research." Journal of business research vol. 117, 312-321, 2020. https://doi:10.1016/j.jbusres.2020.06.015

SKARE, MARINKO; SORIANO,DOMINGO RIBERIO; PORADA-ROCHON, MAŁGORZATA. Impact of COVID-19 on the travel and tourism industry. Technological Forecasting \& Social Change, 163, 120469, 2021. https://doi.org/10.1016/j.techfore.2020.120469

Statista. Number of jobs at risk in the tourism sector in selected Latin American countries due to the coronavirus (COVID-19) pandemic in 2020. 2020a. Disponível em: <https://www.statista.com/statistics/1107431/jobs-at-risk-tourismsector-latin-america-countries-coronavirus/> Acesso em: 16 de outubro de 2020.

Statista. Coronavirus: impact on the tourism industry worldwide. $2020 \mathrm{~b}$. Disponível em: <https://www.statista.com/study/70298/coronavirus-impact-onthe-tourism-industry/> Acesso em: 26 de abril de 2020.

Statista, Dossier on coronavirus (COVID-19) in Brazil. 2020c. Disponível em: $<$ https://www.statista.com/study/71774/coronavirus-covid-19-in-brazil/> Acesso em: 26 de abril de 2020.

Statista. Who's Most Vulnerable to COVID-19's Impact on Tourism?. 2020d. Disponível em: <https://www.statista.com/chart/21391/total-contribution-oftravel-and-tourism-to-gdp-of-selected-countries/?> Acesso em:16/10/2020

Statista. COVID-19's Crushing Impact On International Tourism. 2021. Disponível em: <https://www.statista.com/chart/22691/effect-of-the-pandemic-oninternational-tourist-arrivals/> Acesso em: 08/01/2021 
STEINHOFF, L; PALMATIER, R. W. Commentary: Opportunities and challenges of technology in relationship marketing. Australasian Marketing Journal (AMJ), Advance online publication, 2020. https://doi.org/10.1016/j.ausmj.2020.07.003

UNWTO Reports. International Tourist Numbers Could Fall 60-80\% in 2020. 2020. Disponível em: <https://www.unwto.org/news/covid-19-internationaltourist-numbers-could-fall-60-80-in-2020> Acesso em: 22 de outubro de 2020.

VERGARA, S. C. Métodos de pesquisa em administração. Atlas, 2005.

WALTERS, GABRIELLE; MAIR, JUDITH. The Effectiveness of Post-Disaster Recovery Marketing Messages-The Case of the 2009 Australian Bushfires, Journal of Travel \& Tourism Marketing, 29:1, 87-103, 2012. DOI: $10.1080 / 10548408.2012 .638565$

WHO/Europe | Health emergencies - Novel coronavirus (2019-nCoV), 2020. Disponível em: <https://www.euro.who.int/en/health-topics/healthemergencies/novel-coronavirus-2019-ncov_old>. Acessado em: 20/10/2020

WILLIAMS, ALLAN M.; BALÁZ, VLADIMÍR. Tourism, risk tolerance and competences: Travel organization and tourism hazards. Tourism Management, 35, 209-221, 2013. http://dx.doi.org/10.1016/j.tourman.2012.07.006

YIN, ROBERT K. Validity and generalization in future case study evaluations. Evaluation, 19(3) 321-332, 2013.

YIN, ROBERT K. The Case Study Crisis: Some Answers. Administrative Science Quarterly, Vol. 26, No. 1, pp. 58-65, 1981.

ZENKER, SEBASTIAN ; KOCK, FLORIAN. The coronavirus pandemic - A critical discussion of a tourism research agenda. Tourism Management 81, 104164, 2020. https://doi.org/10.1016/j.tourman.2020.104164 


\section{ANEXO 1 \\ ROTEIRO UTILIZADO PARA AS ENTREVISTAS}

\section{Anexo 1: Roteiro de entrevista semiestruturado para os sócios da empresa}

- História e características da empresa:

○ o que os levou a criar a Café e Viagens;

○ data de fundação e datas marcantes;

- principais passos de direcionamento da empresa;

- como é realizada a organização interna da empresa;

- qual o perfil das outras integrantes da equipe e qual seu papel na história da empresa;

○ informações sobre a concorrência;

○ forma de identificar o custo de uma excursão;

- como conseguiram alcançar os clientes;

- como veem seus clientes atuais, quais os " grupos de clientes" (segmentos) em que estão atuando, descrever um cliente típico de cada grupo;

○ o que os clientes estão buscando quando vão a excursões;

- como se dá o relacionamento com os clientes antes, durante e depois das excursões

○ de que forma as redes sociais são utilizadas;

○ frequência e duração das excursões;

- como é realizada a divulgação das excursões;

○ diferenciais da empresa;

- que outros desafios a empresa já passou, e como superaram.

- História e características dos sócios:

○ história pessoal dos sócios anterior à Café e Viagens;

- experiência com as primeiras viagens que fizeram (sem ser na Café e Viagens);

○ antecedentes profissionais do empresário; 

- antecedentes profissionais da empresária;
- formação do empresário até os dias de hoje;
○ formação da empresária até os dias de hoje;
- desafios pessoais e dificuldades que já passaram.

- Sobre a crise do COVID-19:
- identificar o que aconteceu, como veem e como vivenciaram esse período de crise
- quais respostas a empresa pretende dar ou deu;
○ como estão se planejando;
- sentimentos e expectativas para a continuidade do negócio;
○ quais os planos para 2020;
- como vêem o fato de trabalhar com idosos no contexto de Covid. 